\title{
WCIT 2017 Conference Report
}

\author{
Shamimah Haja Mohideen; Raja Nor Izaliah R. B. Shah; Hasfa Zaima Azizan; \\ Roslan Abdul-Rahim; Ilyani Abdul Khalid.; Mohd Hussin Abdullah, \\ Zurul Na'im Zainol Rashid Wan Sabri Wan Yusof; Nuryazin Ahmad \\ Universiti Sultan Azlan Shah \\ Bukit Chandan, 33000 Kuala Kangsar \\ Perak Darul Ridzuan, Malaysia
}

\section{EXECUTIVE SUMMARY}

The World Conference on Islamic Thought \& Civilization (WCIT) has been organized by Universiti Sultan Azlan Shah (USAS) since 2012 under the Royal Patronage of Duli Yang Maha Mulia (DYMM) Paduka Seri Sultan Nazrin Muizzuddin Shah ibni Almarhum Sultan Azlan Muhibbuddin Shah Al-Maghfur-lah, the Sultan of Perak.

The central purpose of the conference is to provide a platform and avenue for scholars, intellectuals and professionals to come together and engage in a dynamic and vibrant exchange of ideas. The recent WCIT 2017, held on November 20-21, carried the theme of 'Global Peace' and played host to participants and speakers from 22 different countries. Among the speakers were His Royal Highness, the Sultan of Perak, the Malaysian Deputy Prime Minister, the Menteri Besar of Perak, the late Tan Sri Dr. Surin Pitsuwan, the Former Thai Foreign Minster and Secretary General of ASEAN, Sheikh Muhammad Yahaya AlNinowy, the Founding Director of Medina Institute in the US, Col. (Ret.) Ann Wright, retired U.S. Army Colonel and participant of the Gaza Flotilla Challenger 1, Prof. Dr. Bruce Lawrence, a professor of religion at Duke University, USA, Prof. Dr. Dewi Fortuna Anwar of Indonesia, Dato' Ayob Khan Mydin Pitchay, a senior assistant commissioner of the Malaysian Royal Police, Tan Sri Dr. Razali Ismail, a senior Malaysian diplomat, and many other distinguished speakers.
The organizers of WCIT are well aware and are very much concerned about the myriad of issues, problems, and conflicts currently confronting the global citizens. These problems affect and threaten global peace and need to be analyzed, assessed and addressed. With this in mind, the organizers of WCIT 2017 identified the most pressing areas to be discussed and selected six conference sub-themes. They were:

- Social Conflict \& Religious Extremism

- Humanitarian Issues \& Universal Peace

- Islamic Philosophy \& Spiritual Tradition

- Power, Politics \& the Media

- Geo-Strategies \& Global Peace

- Education \& Youth

These themes were explored and discussed in eight (8) forum sessions. There were also the three satellite forum-sessions that discussed the topics of 'Post-new-World Order', 'Women's Role in Peace-Building', and 'Peace in Islam: Bridging Relations with World Communities'.

The 2017 World Conference on Islamic Thought and Civilization was officially opened by His Royal Highness, the Sultan of Perak, but not before his Royal Keynote address, the welcoming speech of the Menteri Besar (Chief Minister) of Perak, and the opening remarks of the Vice-Chancellor of Universiti Sultan Azlan Shah, Tan Sri Prof. Dr. Nordin Kardi. The Sultan's Royal Keynote address on "Global Peace: Towards a More Inclusive and Trusting World Community" helped set the tone, pace, and agenda of the whole conference. 
The first night of the Conference also saw the conference speakers and participants being treated to a sumptuous welcoming dinner at the official residence of the Perak Chief Minister, Datuk Seri Diraja Dr. Zambry Abdul Kadir. It was during this dinner that an "Ambassador Forum"-session featuring seasoned diplomats also took place. The forum was very lively. Everyone present got to listen to the participating ambassadors discuss "Global Peace: Diplomacy and International Relations". In attendance during this ambassador forum were other invited ambassadors, diplomats, foreign dignitaries, government officials, local leaders and academics.

Throughout the conference, participants were not only served with academic and intellectual menu for the brains, they were also literally served with some of the best food of Ipoh, Perak, and also of Malaysia. The choice of food was deliberate in order to showcase Perak as a food heaven. So not only were the conference participants entertained with thought provoking intellectual discourses, they were also treated to satisfying gastronomical delights. In a way, WCIT 2017 appeared as a final highlight of a year-long state campaign of 'Visit Perak 2017'.

WCIT 2017 had hoped to provide a conducive atmosphere for constructive and beneficial exchanges and that, with the convening of the great minds of knowledge and experience, a realistic analysis and assessment of global issues could be achieved, and strategies for resolutions could be attempted. As in every conference, there are bound to be the high and low points. WCIT 2017 had a share of some of those too. But all in all, it can be humbly said that the organizing of WCIT 2017 was a great success. From the participation point of view, the Conference saw more than 1000 people attending the 2-day conference. Included were the 31 paper presenters who presented their papers during the parallel sessions. In terms of a more lasting tangible achievement, the Conference managed to top the icing-on-the-cake with the launching and setting up of the ASEAN Center for Islam, Global Peace and Non-Violence that was announced by the Menteri Besar of Perak at the closing of the conference. This proposed center will have a start-up fund of RM3-Million that was pledged by the Malaysian Deputy Prime Minister, Dato' Seri Dr. Ahmad Zaid Hamidi, who is also the current Minister of Home Affairs.

As the curtain fell on WCIT 2017, WCIT 2018 was already well underway. Both the Universiti Sultan Azlan Shah and the Perak State Government are now looking forward to WCIT 2018 with the hope that WCIT 2018 brings up more interesting topics of discussion for everyone to share and enjoy, and a more vibrant and greater participation from the global world of leaders, academics, and professionals. Universiti Sultan Azlan Shah, the Perak State Government, the WCIT Committee in general, and the WCIT 2018 Secretariat in particular, are calling upon all interested parties to mark their calendar for another eventful gathering in 2018.

\section{INTRODUCTION TO WCIT}

As part of an ongoing effort to engage in and organize academic activities with a view of addressing local, national and international issue affecting Islam and the Muslim community, USAS has been organizing a biennial WCIT since 2012. The third WCIT, which carried the theme "Future World" was held from the $18^{\text {th }}$ to the $20^{\text {th }}$ of October, 2016. The theme was conceived with the hope of laying the foundations and guidelines for the Muslims to venture out and seek the meaning of what constitutes their future world.

The success of WCIT 2016 has inspired both the University and the State of Perak, with the consent of the Royal Palace, to turning this biennial event into an annual affair beginning the year 2017. Thus, carrying the major theme 
of “Global Peace”, WCIT 2017, was conceived.

Conceiving "Global Peace" as the main theme of WCIT 2017 was no accident and it still holds a great deal of significance. Our contemporary world has for long been lurking into a new dark age of social, political and religious intolerance, bigotry and extremism, spiritual ignorance and indifference, and economic inequality. The world has rung its emergency bell calling for those who have wisdom, including leaders, to find a new healing antidote to cure the poisonous conflicts infecting the world today. According to the Global Peace Index, GPI (2017), the global level of peace has slightly improved in 2017 by $0.28 \%$ with 93 countries improving, but the level of peace in 68 countries have deteriorated. Iceland remains the most peaceful country in the world since 2008. Then, New Zealand, Portugal, Austria, and Denmark joined the top index.

The largest regional deteriorations in score occurred in North America, Sub-Saharan Africa, the Middle East and North Africa. There are many contributing factors impacting the peace of a region. One factor is terrorism. According to the Global Terrorism Index (2016), the global economic impact of terrorism reached US\$89.6 billion in 2015. Despite having decreased by 15 percent globally from the previous 2014 level, Iraq for example still suffers its highest economic impact from terrorism, reaching 17 percent of its GDP in 2015. Crisis of war is the second factor which disrupts the regional peace, followed by ethnic cleansing, human forced displacement, suppression of women, lack of education, poverty and internal religious stress. It was with the awareness of these facts that the theme of the conference was divided into several sub-themes.

The sub-themes of WCIT 2017 were: Social Conflict and Religious Extremism; Humanitarian Issues and Universal Peace; Islamic Philosophy and Spiritual Tradition; Power, Politics and the Media; Geo-Strategies and Global Peace; and Education and Youth.

\section{Conference Sub-Themes}

\section{Social Conflict \& Religious Extremism}

Here, the conference sought to critically understand the underpinnings of social conflicts in cultural, political and intellectual terms. The nature and sources of social conflicts were examined and the role of religious extremism in contributing to and exacerbating social conflicts were addressed. The conference also hoped to suggest ways in which conflicts could be peacefully and practically resolved.

\section{Humanitarian Issues \& Universal Peace}

Under this sub-theme, the conference aimed to study and discuss the notion of 'universal peace', if any, and come up with a proposed framework of universal peace. Equally important here was how Islam conceived of universal peace and harmony. The conference also hoped to identify and highlight existing human crises and humanitarian issues and demonstrate how central and closely related humanitarian issues are to the establishment of a universal peace. What was significant was to show that universal peace could never be accomplished without our first resolving humanitarian problems.

\section{Islamic Philosophy \& Spiritual Tradition}

One of the reasons, as one could argue, for the current presence of religious radicalism and extremism in Islam and the Muslim communities - that have subsequently contributed to communal violence and conflicts, and hence, social discord and discomfort is the absence or the lack of awareness and appreciation for Islamic philosophy and the rich spiritual tradition in Islamic history. Radical and extreme views in Islam may be directly attributed to legal and theological rigidity and literalism. It is in these contexts that it was hoped that the conference would be able to demonstrate how the traditions of philosophy and spirituality in Islam could be understood and appreciated as means and mechanisms to 
temper, if not eradicate, extremities in Muslim religious perspectives.

\section{Power, Politics and the Media}

Power and politics have always been the ultimate determinants of global peace and stability. It is undeniable that the dynamics of power relations in politics could make or break world peace. It is here that the conference tried to play a significant role in highlighting these dynamics in relation to social peace and harmony. Another element in the dynamics of the politics of peace is the central role of the media. To what extent the media plays and contributes to the achievement of global peace was an important issue to be understood and appreciated.

\section{Geo-strategies and Global Peace}

There are two notable strategies in global politics and international relations: the geopolitical strategy and the geo-economic strategy. Under this sub-theme, it was hoped that the conference was able to critically discourse on the nature and effectiveness of each of these geo-strategies in attaining and maintaining global peace and social harmony.

\section{Education \& Youth}

It is arguably a known fact that education is extremely vital to the development and success of a nation. At the heart of a nation's social and intellectual health is education. It is through education that ideological radicalism and extremism could be circumvented and avoided, just as it is through education that global peace and universal harmony could be conceived and acquired. It is therefore the role of the proposed conference that these facts get understood and articulated. At another level, one easily admits that the youth plays a very vital role in the future of any given nation. The youth must thus ensure that not only is education developed and safely guarded, they must themselves make certain that they be educated in the first place. The conference therefore served as a platform to express and discuss these important dynamics that organically connect education, youth, peace and the future.

\section{Post - New World Order}

The world economy and markets have gone through considerable changes over the years. The current market is now seeing a crash in the oil and gas industry, the transition of the economic powerhouse label from the West to the East with China spearheading the ascend, heightened geopolitical tensions, and others, have affected worldviews across the globe. The transformational change in finance and society has a direct impact on the moral economy, and the behavioural economy. It is a given fact that the economy has a direct correlation with the climate of the world politics.

Economic powerhouses have the power to dictate the direction the world is going and moving toward. The Asian continent is on the rise with China and India continuing to outpace each other as the world's fastest-growing economy, despite the global slowdown. This phenomenon is seeing China emerging as one of the formidable political powers, rivalling the powers from the West. The changes in the dynamics of the international political moves and discourses require calculated and strategic choices to ensure the stability of global peace. It is therefore inevitable that we have to reshape our way of thinking due to the wind of change.

\section{Women's Role in Peace Building}

Women can be either victims of conflict or agents of peace building. Many a time, women have averted conflicts and have been responsible for resolving conflicts. Peacebuilding needs the involvement of women. During violent conflicts and wars women are forced to assume new roles as heads of families, providers, combatants, and freedom fighters. Women's roles in peacebuilding across conflict areas in the last decade highlight the importance of 
moving women beyond the "humanitarian front of the story." Women have and can continue to influence peacebuilding processes so that they go beyond defining peace as the absence of violent conflict and focuses on the principles of inclusion, good governance and justice. Women need to be present to discuss issues such as genocide, impunity and security if a just and enduring peace is to be built.

\section{Peace in Islam: Bridging Relations with World Communities}

Recent political events in the world have thrusted Islam and the Muslims into the spotlight, and debates on Islamic extremism and religious intolerance, and the integration of Muslims into societies have become hotbutton issues. It was hoped that the Conference brought about a good appreciation and greater understanding that Islam is not a threat to the world and Muslims are not in conflict with others, and that only through the dialogue of cultures and the integration of Islam and the Muslims in societies that the World will be a safer and a more peaceful place to live in. Through discussions and exchanges, it is hoped that the conference would generate the sufficient and necessary conditions for a more realistic analysis and assessment of global events and conflicts within social and political realities.

\section{CONFERENCE IN MOTION}

The conference was conducted for two days from $20^{\text {th }}$ to $21^{\text {st }}$ of November 2017, at Casuarina Hotel@Meru, Ipoh, Perak, Malaysia. It began with welcoming speeches by Tan Sri Prof. Dr. Nordin bin Kardi, the Vice-Chancellor of USAS and YAB Dato' Seri Diraja Dr. Zambry Abd Kadir, the Menteri Besar of Perak. Following the welcoming speeches was the keynote address by His Royal Highness Sultan Nazrin Muizzuddin Shah, the ruler of the State of Perak Darul Ridzuan. Following the Royal Keynote address were the conference forum sessions conducted by prominent world-renowned speakers. The conference ended with the closing speech by the Malaysian Deputy Prime Minister, YAB Dato' Seri Diraja Dr. Ahmad Zahid Hamidi.

\section{Welcoming Remarks by Tan Sri Professor Dr. Nordin Kardi}

The USAS Vice-Chancellor extended his warm welcome to His Royal Highnesses, the Sultan and the crown-prince of Perak, the Menteri Besar of Perak, dignitaries, guests and participants. $\mathrm{He}$ expressed his sincere hope that WCIT would be constructive to the world and to the future.

\section{Welcoming Speech by Dato' Seri Diraja Dr. Zambry Abdul Kadir}

In his welcoming address, the Menteri Besar (Chief Minister) stressed on the importance of mutual trust and respect in order to maintain harmony in a multi-confessional, multicultural state such as Perak. Perak's different religious traditions offer many resources which could teach us about good relationships characterized by honesty, compassion, generosity and love. In this way, peace, prosperity and non-violence may be achieved. Unfortunately, currently, Islam is often demonized and terms like Islamophobia, Muslim-phobia, Muslim bigotry, terrorism and extremism circulate freely in social media. This is a result of fear and prejudice fermented by global geo-politics.

WCIT is an important and inclusive platform for the discussion and deliberation of ideas, methods and approaches in addressing global issues and finding non-hostile solutions. It was hoped that WCIT would be the preferred discourse platform for an inclusive and diverse understanding of the promotion of respect for others in accordance with the world's aspiration for unity, global peace and non-violence. 
GJAT | DECEMBER 2017 | VOL 7 ISSUE 2 | 12

ISSN : 2232-0474 | E-ISSN : 2232-0482

www.gjat.my

\section{Royal Keynote Address by His Royal Highness Sultan Nazrin Muizzuddin Shah}

His Royal Highness, the Sultan of Perak conveyed his Royal Keynote address on "Global Peace: Toward a More Inclusive and Trusting World Community". He began with a thrust: "How peaceful is our world today?" He then went on to address the conference theme, citing published sources every now and then.

According to the Global Peace Index, the world is 0.28 per cent more peaceful now in 2017 than it was in 2016. This took into account the withdrawal of US and UK troops from Afghanistan, and the ceasefire between armed rebel groups and the Columbian government. Decreased militarization and a reduction in violent crime and homicide also accounted for this improvement in the peace measure.

Still, the Institute of Economics and Peace reports that the world is less peaceful than it was 10 years ago. This downward trend is due to the threat posed by terrorism, nuclear missiles and refugee crises. Deaths caused by terrorism have increased by 247 per cent in the past decade, 11 million people have been displaced as a result of the Syrian war and thousands of Rohingya Muslims are suffering as a result of a "textbook example of ethnic cleansing".
The King also spoke about the longstanding problem of the unequal distribution of wealth between the richest and the poorest in the world. On top of that, the world is also facing the unequal distribution of global peace. So, what is this global peace that we are striving so hard to achieve? What does global peace look and feel like? Leading proponents of peace have said that peace is not merely the absence of war. To His Royal Highness, peace should also be the absence of want and fear. It is religious freedom and respect for different cultures. It is the acceptance, understanding and celebration of diversity in all its many forms.

His Royal Highness further argued that a truly peaceful world is one that is characterized by two Islamic values: trust (amanah) and inclusivity (ta'ayush). These values promote the idea of learning to live together by showing mercy. The principles of trust and inclusivity, said the King, must always be kept in mind as the world sought to attain global peace, to eradicate conflict, and also to establish a more trusting and inclusive world community where each and every individual is valued and respected. The realization of these two principles are not just the goals of global peace but also the means by which peace could be achieved. 


\title{
Distinguished Session
}

\section{Panelists:}

\author{
Surin Pitsuwan (Former Secretary General of ASEAN) \\ Muhammad Yahaya al-Ninowy (Founding Director of Madina Institute) \\ Ayob Khan Mydin Pitchay (Dpty Commissioner of Royal Malaysia Police)
}

The panelists had an intricate discussion about the global peace. The first speaker talked about the pursuit of peace. The second panelist touched on the definitions of peace and non-violence and the third panelist shared his experience and expert knowledge in maintaining the country's security from internal or external threats.

Surin Pitsuwan started the session by mentioning how the greatest religion reveals religion. He added that the world is full of diversity and people got caught by the symbol of their religion. There are differences in the way they understood religion, their understanding of right and wrong and their idea of good and evil.

Shaykh Muhammad Yahaya Al- Ninowy shared his wisdom on the different definitions of peace and non-violence. According to him, Islam makes its distinction between peace and laid down foundation and practical examples for both peace and non-violence. Islam looks at peace as an environment that is conducive to love. People can never enter Paradise until they believe, and they will never believe until they love. This shows how significant love is in Islam.

For Ayob Khan, what we need are comprehensive strategies and approaches in dealing with extremists, militants or terrorists. For example, the Daesh has drastically altered the security landscape and created new challenges. They are well structured by disseminating their ideology, recruiting new members, planning attack, exploiting social media, networking and procuring fund.

\section{Social Conflict and Religious Extremism}

\section{Panelists:}

Bruce Lawrence (Prof. of Religion, Duke University, USA)

Murad Merican (Centre for Policy Research and International Studies, USM)

Mohd Kamarulnizam Abdullah (Dean, Ghazali Shafie Graduate School, UUM)

In this session, the speakers discuss the concepts of the three isms- fundamentalism, extremism and terrorism. Bruce Lawrence began the session with the topic of religious fundamentalism. Fundamentalists, says Lawrence, refer to a section of protestant Christians who bore a separatist attitude towards modernity. However, at present, it is used to relate to the most extreme believers of every religion in the world. It is important to recognize social change and social conflicts. Islam is also one of the religions riddled with fundamentalists.

Murad Merican highlighted the point that when people talk about extremism, it automatically conjures the image of Islam. It is either extremism in Islam related to what Muslims do or just anything related to Islam. According to him, extremism is not in the form of action in the first place, but more towards the idea in modern times. Moderate Islam is something that we need to be aware of. So, those who 
object moderate Islam are called extremists or fundamentalists.

For Mohd Kamarulnizam Abdullah, managing the threat of religious terrorism by looking at the background of the threat, the contributing factors and the solutions of the problem is of great priority. Terrorism, fundamentalism, extremism, and political religious extremism will always be associated with Islam. Those people who committed those mentioned problems are trying to politicize Islam to suit their interest and benefit.

\section{Islamic Philosophy and Spiritual Tradition}

\section{Panelists:}

Shaykh Muhammad Yahaya Al-Ninowy

M. A. Muqtedar Khan

Shaikh Abdul Mabud

This session relates two concepts, philosophy and spirituality. Philosophy is a tradition that comes straight to us from the ancient Greek thinkers. To them, reality was riddled with universal laws that governed everything and that needed to be understood and lived in accordance with. Philosophy is the domain of wisdom, knowledge and understanding about reality, an explanation of the way things are.

Spirituality on the other hand, resides in the realm of truth, spirit and moral judgement. It always includes philosophical explanations of the world, but those philosophical aspects are the backdrop for the main event which is direct instruction about how to live. For Muqtedar Khan, people with hikmah, those who do zikr and reflect on the signs of Allah are the ones who can extract the most beautiful interpretation of the Qur'an, the spiritual and philosophical. $\mathrm{He}$ also added that diversity of interpretation and judgement on what is moral is the most beautiful part of our human khalifah agency.

To Muhammad Yahaya Al-Ninowy, human beings are complex because they are divided by the earthly part (body made of clay), and the heavenly part (soul). This makes them potentially the best of creatures or otherwise. The Qur'an and Sunnah are our spiritual GPS that create the path and guide the Muslims.
They tell us the purpose of our existence, our role and place in this world, and our direction.

M. A. Muqtedar Khan introduced his speech by posing the question "What is Islam?" He then provided the understanding of Islam from different perspectives. From the orthodox, it is dictated by a legislation (Shariah) and guides one's faith (Aqidah). For the Sufi, it is a divine self-disclosure of Allah SWT (Tijalli). Allah introduces Himself and reveals Himself to us through text and creation.

Shaikh Abdul Mabud spoke about philosophy as a general precept. Global philosophy transforms us to become wise. It trains our soul to stay away from sins. The concept of Allah and its universe is an advance philosophy. In order to practice it one needs to go into Sufism to participate in the process of remembrance of Allah. In order for the young and moderate to accept and practice philosophy, the philosopher or theologian needs to talk to them using their language. The young believe that everything they have done is for them and for the world to be a better place to live. They rarely connect their attitude with religion or God. Thus, it is our job to explain it naturally and in their own language how to relate things with religion. 


\section{Geo-Strategies and Global Peace}

\section{Panelists:}

Dewi Fortuna Anwar (Former Deputy for Government Policy Support in the Secretariat of Vice President of Indonesia)

Aileen San Pablo- Baviera (Professor, Asian Centre - University of the Philippines Diliman)

In this session, Dr. Aileen spoke about international relations, with special emphasis on those involving China, and Dewi Fortuna gave valuable recommendations on how to form a peaceful country and manage internal as well as external conflicts.

Prof. Aileen San-Pablo was asked on how we the ASEAN countries should be moving forward with China. China is significantly large in population and in production. It was also said that China's development might not only affect India but also around the world. China always cooperates and comes forward to bring global peace with other countries. China does want to find peace but they debate or question the kind of peace: peace with the government or among individuals? Peace in terms of respect or security? Aileen believed that the topic of cooperation is really an important global issue.

For Prof. Dewi Fortuna Anwar, understanding the dynamics of power is essential in ensuring peace. She highlighted that the top ten peaceful countries in the world are dominated by European countries and at the bottom is dominated by Muslim majority countries. This happened because of the internal conflict that caused a lot of damage. If the internal affairs are being well managed or administered, countries would be strong enough to avoid external interference and this in turn would ensure the positive peace. She listed a few characteristics of a peaceful country. Among them are the country is predominantly democratic, well-governed, have a good index of integrity (anti-corruption), and have good policy on social welfare (social equity). She also listed several characteristics of a low peaceful country. These are those engulfed in internal conflicts which could attract external intervention in order to get back up. Other characteristics are the lack or even absence of democracy, human right protection, social equity and social justice. These problems will eventually bring in external interventions.

\section{Panelists:}

\section{Ambassador Session}

\section{Dewi Fortuna Anwar}

Surin Pitsuwan

This session was held in the grand residence of the Perak Minister over an elegant dinner that brought together guests from various ethnic background, culture, religion and nationalities. Truly reflecting the spirit of global peace and unity. The session was opened by the Menteri Besar Perak Dato' Seri DiRaja Dr. Zambry
Abd Kadir. Following the opening, Dewi Fortuna delivered her eloquent speech on what constitutes as a good political system. Then Surin Pitsuan proceeded with his inspiring speech on multilateralism. Dewi Fortuna began with espousing the concept of diplomacy. To her, diplomacy is usually associated with 
international relations. Diplomacy means to negotiate and have dialogues. Diplomacy fails when one has to resort to force in trying to get the desired action or decision from the other party. Also, a good political system is one that takes into consideration the important role of citizens in developing peace in a country. Developing peace in a country needs the trust of the citizens. Trust cannot be developed if there is not a very inclusive participatory political system. A country needs democracy where people can have a say in what sort of government they want to have, what sort of policy, who they want to elect as their leader, how long they want the leader to stay, etc. Democracy alone is not enough because conflict can still happen in a place with democracy. Democracy, if misused has the tendency of winner takes all - majoritarianism.

Focusing on multilateralism, Surin Pitsuwan believed that multilateralism is usually a common practice in international relations but it is in trouble now because many nations now prefer to conduct one on one dealings.
Countries are now practicing pro-nativism or pro-majority without recognizing that the world is becoming more connected, integrated, and interdependent. Surin awakened us to the reality that most countries have become so multiracial that the distinction between majority and minority communities or native and nonnative communities has become irrelevant such that 7.4 billion people on earth are becoming considered as minority.

To create a world of reconciliation, accommodation, we need to take care of every minority that comprises the global community. We need new consciousness to have the sense of belonging, ownership, contributing and participating in this global community together. In order to lead the world, there must be a sense of togetherness. Work together, respect each other and create space for each other despite their differences in ethnicity, nationality and culture. Democracy is not just about the majority. It is also about respect for the minority.

\section{Panelists:}

\section{Power, Politics and the Media}

Chandra Muzaffar (Board of Trustees Yayasan 1 Malaysia)

Greg Barton (Deakin University, Australia)

Tan Seng Giaw (Deputy Chairman, Public Accounts Committee)

Ahmad Fauzi Hamid (Professor of Political Science, USM)

of report undoubtedly affect the credibility

Speakers in this session stressed that it is the media's responsibility to become the purveyor of truth. They must therefore investigate the truth of their facts; verify their facts with strong and sufficient evidence before reporting and publishing them. The media has a strong influence on the public. A large segment of the public relies on their reports. Reports must not be based on mere generalizations, biases, negative emotions or exaggerations. Such types and integrity of the media as the source of news. The Qur'an stresses on the importance of investigating the authenticity of facts before spreading them to the public.

Dr. Chandra Muzaffar discussed the functions of the media in perpetuating the truth. However, according to him, the global media do not play its role as they often camouflage and conceal the truth, especially on issues related to conflicts and war in Muslim countries. Referring to the 
Balfour declaration as an example, the media abandoned the Palestinians and gave the absolute power to the Jews. The media does not focus on the issues of Palestinian being marginalized in their own country, but rather focus on the mandate for the Jews. The main reasons behind this mandate are to finance the WWI and strengthen grip over Muslim countries, truths that are hidden by the media.

For Greg Barton, human beings are highly wired to think in narrative terms and see observable patterns. This makes members of the public easily influenced by the media's sensational story- telling effects. On the part of the media, it is much easier to tell a bad news story than a good news story. He related the bias against Muslims that happen in the Western media with Islamophobic individuals who are very quick to report and spend time on events of terrorist attacks if it is linked to Islamist groups such as Al-Qaeda or ISIS. Terror attacks receive 5 times more media coverage if the perpetrator is a Muslim. The fact is that there were more terrorist attacks from non-Muslims than the so-called Islamist groups. Greg Barton also discussed the factors behind terrorism. Muslim countries get affected the most from it.

To Ahmad Fauzi Hamid, an element in the dynamics of the politics of peace is the central role of the media that is supposed to be the purveyor of truth but instead are distorting the truth. Ahmad Fauzi refers to such journalist as 'intellectual prostitutes' as they feel they are more accountable to the editor than to their ethical and intellectual principles.

In Malaysia, there is concern that Islamic schools have become a breeding ground for militant Islam. Consequently, the authorities are seeking to relocate religious education within the national school system to after school classes and to enforce close supervision of private Islamic schools. This was the result of madrasahs having been portrayed as being terrorist extremists. Generalizations about religious schools were made based on one case of an under-aged girl who got caught with being involved in extremism.

In Tan Seng Giaw's observation, the media is a powerful and influential tool. So powerful that it helped Donald Trump beat Clinton during the election when he used Twitter effectively to gather the crowd. However, what is powerful for good is also powerful for evil. Allegations of crime, corruption or any other malpractice without any basis can destroy the reputation of an individual. Being truthful and fair is the value of all civilizations. It is the responsibility of the media to report the truth. Seng Giaw believed that in order to report the truth, the media needs to have evidence before making serious accusations against individuals and not be too quick to 'castrate' a person before he is proven guilty. 
GJAT | DECEMBER 2017 | VOL 7 ISSUE 2 | 18

ISSN : 2232-0474 | E-ISSN : 2232-0482

www.gjat.my

\section{Humanitarian Issues and Universal Peace}

\section{Panelists:}

Ann Wright (Retired U.S. Army Colonel)

Fauziah Mohd Hassan (Deputy Chairperson, Aqsa Syarif Mohd Helmi Ibrahim

This session addresses humanitarian issues. One part of the session relates the trauma that is happening in some parts of the world, with special attention to starvation in Somalia and ethnic cleansing in Myanmar. The other part relates humanitarian efforts and contribution in aiding the victims through organizations that give charity and development programmes. The speakers of the session were Col Ann Wright, former U.S. Army Colonel, Dr. Fauziah of MyCare and Dr. Mohd Helmi from Asean Rohingya Centre (ARC).

Ann Wright began by sharing with the audience her personal experience with the U.S. Army. She resigned from the US army in 2003 to support the cause of peace and to work in making a change for women and children. In her speech, Ann Wright raised issues in humanitarian aids. There are refugees always seeking for shelter and help. The good news is that the amount of help for humanitarian aids is extraordinarily increasing.

Fauziah Mohd Hassan of MyCare spoke mainly about MyCare and the work it does. MyCare is a non-governmental organization (NGO) with the aim of carrying out charity activities, providing financial assistance or goods and shelter to those in need. Its vision is to nurture communities towards a caring and peaceful world. Its mission is to galvanize resources and expertise of Malaysians and the global community towards a caring and peaceful world. The objectives of MyCare are: 1) To disseminate accurate information in achieving comprehensive understanding on humanitarian issues; 2) To garner financial support and human expertise in an accountable manner; 3) To channel financial support diligently and provide appropriate solutions to the beneficiaries; and 4)
To network and collaborate professionally with local and international organizations. MyCare is driven by the motto, 'Nurturing Humanity, Making a Difference.'

Mohd Helmi Ibrahim spoke about the Rohingya crisis, described by UN as a textbook example of ethnic cleansing with genocide, rape, religious oppression, mass exodus etc. The Rohingya people have lost their human rights. Asean Rohingya Centre (ARC) organized a meeting dedicated to the suffering of Muslim minority in Myanmar to raise awareness at the regional level and put an end to abuses. Muslim, Christian and Buddhist leaders were present. 2018-2028 is declared as the international decade of solidarity with the Rohingya

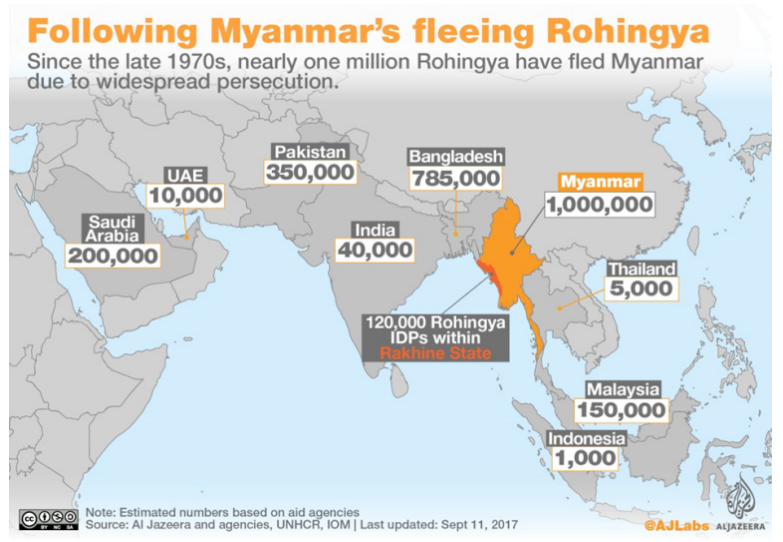

The cause of the Rohingya crisis is racial discrimination by right wing extremism. People of Rohingya differ from the Buddhist majority of Myanmar in their religion, skin color, and culture. However, this minority group was already rightful citizens of Myanmar according to Section 11 of 1947 constitution Section 4 (2) of 1948 citizenship Act. As a result of persecution, around 605000 Rohingya people have fled to Bangladesh since August 25, 
2017, mostly residing in temporary makeshift settlements. In Malaysia there are 62000 refugees and asylum seekers. Access to basic services such as shelter, healthcare services and education is challenging for refugees and asylum seekers in Malaysia as the country is not a signatory to the 1951 Refugee Convention or
Its 1976 Protocol, nor is there a legal framework to manage these persons of concern.

\section{Education and Youth}

\section{Panelists:}

Hafiz Mahmood Khatib (Attorney at Law, MK Lawyers \& MK Group of Companies, South Africa)

Syed Muhammad Khairudin Aljunied (Malaysian Chair of Islam in Southeast Asia, Georgetown University)

Norazah Mohd Nordin (Dean, Faculty of Education, UM)

\section{Sheikh Hafiz Mahmood Khatib}

In his presentation, Sheikh Hafiz Mahmood Khatib depicted the beauty of the older and younger generations working together and complementing each other. The Sheikh recalled the Qur'anic story of Abraham and his son, Ishmael where Abraham said to his son, "Oh my son, I had this vision where I had to sacrifice you." Ishmael then replied, "Oh my father, perform what you have been commanded to do, for you will find me steadfast in full submission," (Q.S. 37: 101). This incident illustrates how the older generation consults youth and how youths tend to follow examples rather than exhortations in long khutbahs. Later, this father and son, built the Kaabah together, an action which represents wholeness and perfection, building a structure which also represents wholeness and perfection.

Actions of the older generation have an impact on the younger generation. Thus, education and the teaching from more experienced people cannot be separated. Also, the seeking of knowledge should not be limited to the youth only, as one of the objectives of education is to bring about good character, to become better human beings. Knowledge feeds the minds of human beings, just as food feeds their bodies and love feeds their hearts.

In education, moderation is the key. This approach avoids extremism. There is also a need to move away from the dichotomy or the dilemma faced by youths as to whether to be a sheikh or an engineer when in actuality, one can be both.

In closing, the Sheikh stressed that the youth of today are NOT the future generation. They are, in fact, the CURRENT generation and advised the audience to bring along young people when travelling in order for them to see the world.

\section{Syed Muhammad Khairudin Aljunied}

In Dr. Khairudin's spirited and energetic delivery on this topic, the audience was introduced to the term 'fedupism", a protest culture amongst the youth of today. According to Dr. Khairudin, 'fedupism' is a culture of dissent among the youth because they are "fed-up" with the current state of the world and with how things are being done and carried out (i.e. the system, the lectures, the status quo, the traditional approaches and so on). In the currently globally connected world, 
there seems to be an explosion of knowledge but an implosion of wisdom

The Muslim world is a youthful world; it is full of youth with so much untapped potential. Islam should be taught in context (learnt in society) and not just in text (learnt in isolation). We also have to be aware of New Age Muslim youth subcultures to curb misinterpretations that could lead to extremism. For example, music, such as hip hop, has become the medium to learn Islam.

Currently, Islamic Higher Education lags behind others. None of the universities in Muslim countries ranked in the Asia-Pacific innovative universities list. This is a point on which we all need to ponder.

We need to move forward, and in order to do that, we also need to look backwards as in the words of Malcolm X, “A person who doesn't know their history, do not have an identity, and people without identity, will fall for anything and everything."

The speaker recommends several steps to be taken. We need to stop whining and become more cosmopolitan and open minded. We need to create more knowledge driven networks. We need to accept ideas out of the ordinary and we need to read, read, and read. Among others, Dr. Khairudin recommended a book on the Qur'an written by Bruce Lawrence.

\section{Professor Dato’ Dr. Norazah Mohd. Nordin}

Dato' Dr. Norazah Mohd Nordin spoke about the United Nation's Sustainable Development Goals where the fourth of these goals is Quality of Education. Based on the World Economic Forum there are 10 expected skills to be acquired for the $21^{\text {st }}$ century. Thus, there is a need for the redesigning of the educational system and model in preparing Malaysia for the $4^{\text {th }}$ Industrial Revolution. At present, our youth is exposed to the explosion of information and exposure, making them open to changes. They need to be nurtured in order to prepare them for the challenges ahead.

According to the Professor, the new generation students like everything to be personalized and they also love connectivity. They love to create personal space and these account for the popularity of social media such as blogs, Instagram, Facebook, and so on.

Technology is in the forefront of the challenges ahead. Technology can be negative and disruptive. For example, when automobiles and tractors were developed, farmers lost their jobs. When highways were built, towns were bypassed and this affected the livelihood of the townsfolk. With automation, many jobs became irrelevant.

In order to face the challenges of the $4^{\text {th }}$ Industrial Revolution, we need to always be knowledgeable. We need to be self-directed learners. Parenting, for example, requires lifelong learning. "The illiterate of the $21^{\text {st }}$ century are not those who cannot read but those who cannot learn, relearn and unlearn" (Alvin Toffle).

The learned professor ended her presentation with this wonderful quote from Abu Bakr asSiddiq, "Knowledge is the life of the mind." 


\section{Post-New World Order}

\section{Panelists:}

Tan Sri Razali Ismail

M. A. Muqtedar Khan

\section{Understanding US Multifaceted Decline:}

\section{Prof. Muqtedar Khan}

Taking on the theme of understanding US multifaceted decline, Muqtedar Khan gave the audience some very enlightening and thoughtprovoking input about the decline of the United States of America as the world's dominant power and its global impact especially vis-a-vis the Muslim world. The US diplomatic, military, and economic internal cohesion is falling and the world needs to know the implications of this situation.

For one thing, global multilateral order will suffer. America's decline enhances global insecurity, reduces resources for global development and retards globalization. The world needs to ponder whether it is ready for America to be a challenger rather than the maintainer of the global order. To the Muslim world, is America a friend or foe? On the one hand, America is an invader, manipulator, dominator, exploiter and impediment. On the other hand, America is also a balancer, capacity builder, security provider, a knowledge and investment source and an inspiration.

The world needs to ponder on whether it prefers China, India or Russia to take over the role of the US if the US is no longer dominant. We also need to be aware that although the US is declining, it is still dominating. It remains the world's most important figure. It is still no.1 with regard to economy and innovativeness, and it is still way ahead in terms of science, research and technology. America's decline is, in fact, with respect to itself; it does not mean that it will lose its relative pre-eminence with regards to other nations.

\section{Tan Sri Razali Ismail}

Tan Sri Razali, a distinguished and seasoned diplomat, gave the audience the benefit of his vast experience and knowledge in sharing his thoughts on the topic of post-new world order. He began by openly declaring that he personally does not want America to decline and hopes that the US will continue to be a benign power. The Tan Sri defines world order as the attempt by the world's victorious powers which are rule-based.

On the downside of globalization, Razali Ismail highlighted that globalization benefits 'who is in charge'. The capitalistic economy is where the rich get richer. Globalization has caused a lot of people to feel vulnerable and insecure due to the uncertainty of the economic situation. It has become a very unfair world.

The Tan Sri touched on how Malaysian and ASEAN countries have high end industries, how modernization has left a lot of casualties across ASEAN, how marginalization is a serious problem, and that governance is more important than democracy. Governance is allowing the people to express and make judgements and governments, specifically the Malaysian, Thai and Indonesian governments, need to believe and have faith in the people. The Tan Sri exhorted that politics that does not include the people should not be accepted and that our youth should not be left to be thoroughly influenced by the West but to be encouraged to make up their own minds. 
GJAT | DECEMBER 2017 | VOL 7 ISSUE 2 | 22

ISSN : 2232-0474 | E-ISSN : 2232-0482

www.gjat.my

\section{Women's Role in Peacebuilding}

\section{Panelists:}

Col. (Ret.) Ann Wright

Dr. Fauziah Mohd Hassan

Prof. Dr. Dewi Fortuna Anwar

Dr. Fauziah acknowledges the Qur'an's recognition of women in special chapters, particularly An-Nisa, Mujadilah and Mumtahanah. Surah Al-Ahqaf acknowledges the difficulties women go through during pregnancy and delivery. Surah Al-Rum on the other hand recognizes a woman's role as as a wife - signs of Allah's Greatness. Surah At-Taqwir forbids the killing of daughters. A woman's rights to dowry and inheritance is mentioned in many lines of Surah An-Nisa.

In Malaysia, women only make $15-16 \%$ in decision making roles! The aim is to achieve at least $30 \%$ ! Security Council of UN Resolution unanimously, calls for broad participation of women in Peace-Building and Post-Conflict Reconstruction.

Women's skills and social positions give us different perspectives on issues of peace and conflict. Across the globe, women have demonstrated their abilities to achieve common ground and work effectively to better their communities in instances where men have failed. NGOs provide framework and guidelines for the community to involve in peacebuilding activities, rebuild the community by educating

and giving awareness, bridge the gap between different cultures and faiths and provide social services or assistance to the needy

In her speech, Dewi Fortuna Anwar highlighted that women are the primary victims in conflicts such as sexual violence. She added that women are often marginalized in peace processes, given that they only make up $2 \%$ of chief mediators; $4 \%$ of witnesses \& signatories; and $9 \%$ of negotiators. Marginalization of women seen to contribute to failure of peace settlements for the long term. There is a growing international awareness of the need to recognize women's critical role in conflict prevention and resolution. The Landmark UN Security Council Resolution S/RES/1325 of 31 October 2000 on women, peace and security reaffirms the important role of women in conflict prevention and resolution of conflict; peace negotiations; peace-building; peace-keeping; humanitarian response; and post conflict reconstruction. It calls on all parties to take special measures to protect women and girls from gender-based violence, especially rape and other forms of sexual abuse in time of armed conflicts. 


\section{Panelist:}

\section{Peace in Islam: Bridging Relations with World Communities}

Shaykh Muhammad Yahaya Al-Ninowy

The Shaykh started the session with a bang. Quoting "A text out of context is a pretext," he then expounded this strong statement by quoting examples from both the Qur'an and the Bible. The Bible, he noted, commands its followers "to love your neighbor as yourself" but it also commands them to "Kill men and women, children and infants, oxen and sheep, camels and donkeys." The Bible asks believers "to turn the other cheek", but it also says that "The person who doesn't have a sword should sell his coat and buy one." The Qur'an states that "whoever kills a soul unless for a soul or for corruption [done] in the land - it is as if he had slain mankind entirely." But the Qur-an had also exhorted the believers to "Kill the idolaters wherever you find them, and capture them, and blockade them, and watch for them at every lookout ..." It all depends on the situation and the interpretation.

The Shaykh noted that people will find a text that suits their needs in the religious book. For example, violent extremists justify their actions by using faith. In actuality, most conflicts are fueled by greed, envy and ambition.

Compassion is a true test of faith. God is good to His servants; He gives ihsan to all, irrespective of whether His servant is good or bad. This is, in fact, the central theme of Islam - to be unconditionally compassionate, to have compassion for both the good and the bad. AlNinowy questioned, "If you're good only to those who are good, then what good are you?" According to the Shaykh, it is a big transition for those who are locked in violent and negative thinking to be compassionate towards others as commanded by Islam and preached by the Prophet of Islam. "None of you is truly a believer until he wishes for his brother what he wishes for himself," says Muhammad, the Prophet of Islam. We therefore need to focus on character building (tarbiyyah) of the people with emphasis on the universal message of Islam.

Shaykh al-Ninowy continued to observe that the world is becoming dangerously polarized with worrying imbalance of wealth and power. Alienation and humiliation have erupted in terrorist atrocities. The greater Muslim World hence needs to build bridges of love and civilization. The solution to building such bridges is: education, education, education. Quoting Derek Bok, the former President of the prestigious Harvard University, al-Ninowy intimated, "If you think education is expensive, try ignorance." To Shaykh al-Ninowy, there must be an axis that works on promoting shared values, supporting local solutions, building local capacity in leadership, and strengthening the roles of institution and religious leaders. The provision of citizenship should be broadened, and respect for the rule of law, faith and a common understanding must be promoted. "We must be vibrant and work together for a better world." These were his last words. 


\section{COMMENTARY/DISCUSSION}

The conference has drawn attention to how Muslims have been victimized from nonviolent to violent ways. At the non-violent level Muslims are victims of prejudice by the media where they are portrayed negatively with false accusations, often labelled as terrorists and extremists. At the most violent level that disturbs the entire Muslim world are the persecutions of Muslims particularly in Palestine and Myanmar.

The theme of the conference was 'Global Peace' which is in line with the meaning of Islam. Shaykh Muhammad Yahya talked about the original meaning of 'rahim' which is love. Islam is a religion of peace that teaches us to love. It is however, ironic to find facts from the Global Peace Index that countries which are least peaceful are the Muslim majority countries. This is because Muslims also face internal conflicts among themselves. As Prof. Dr. Dewi Fortuna said, Muslims need to manage their internal conflicts first to avoid external interference. Forming a good society is important to minimize internal conflicts. A good society begins with good leadership and governance. This statement was also expressed by Prof. Greg Barton. A country with good governance has stable economy and politics which practices democracy, considers the welfare and rights of the people and most importantly, minimizes corruption. The actions of a minority group of Muslims themselves spoil the reputation of Islam with leaders using religion for their hidden political agenda and terrorists justifying their actions by misusing Islam for their own personal interest and greed. This is what causes extremism according to Prof. Bruce Lawrence.

Some of the sessions addressed the issue of extremism. Islam teaches us to be moderate in all aspects of life including religion, worship and ideas. Dr. Murad Merican pointed out, so did Bruce Lawrence earlier, that extremism exists among people of all religions and the term should not only be used to describe religious beliefs and practices, but also extreme, unethical and inhumane actions. Anything that robs people of their basic human rights and dignity such as colonialism and ethnic cleansing are also examples of extremism.

With such a theme as 'Global Peace' the Conference is, in true fashion, appealing to the local and global community to have tolerance towards one another and be willing to co-exist despite differences in ethnicity, religion, gender, political affiliation, etc. The world is getting smaller. We are now part of a global community. Rather than getting disturbed by the differences, why not celebrate the diversity? Focus on the contribution from all that can improve the quality of life. Rather than competing for power, the community at the local and global level need to collaborate in combatting issues that affect the welfare and security of all such as poverty, diseases, climate change, forced migration, food and energy scarcity and terrorism. Issues of climate change, forced migration, food and energy scarcity have also been discussed in WCIT 2016.

WCIT has traditionally included youth not only as an important component of its academic discourses, but also more so visibly as a conference sub-theme. This is only because of the fact that communal and global issues discussed have great implications on them. They represent our future and they are our future leaders. Our actions today can influence the generations of tomorrow. The younger generation learn and follow the examples we set, not our lectures with "Do as I say, not as I do." According to Dato' Dr. Norazah, developing the youth involves redesigning the educational system.

What we are usually reminded in WCIT conferences is that there is a big gap between the ideals inculcated by the Qur'an and the Sunnah and the actual practice of people today including the Muslims. Are we really out of the dark ages? Or are we still in the modern Dark Age? Perhaps many Muslims need to revert to the Qur'an and Hadith, the everlasting and 
valuable source of guidance that transcends all places and time.

\section{THE CLOSING}

\section{Closing Remarks by the Perak Menteri Besar}

In his closing remarks, the Menteri Besar thanked guests and participants for their presence and participation at the conference. He hoped that everyone had found it enjoyable, rewarding and thought-provoking. He himself found the discussions enlightening and insightful.

The Chief Minister opined that peace is forever an open topic and thus, there could never be "closing remarks". Every time mankind close their hearts to compassion and love, or their minds to different ways of considering the world, or their eyes to not see the suffering of others, doors to discord, hatred, and inhumanity are opened.

HRH the Sultan of Perak had earlier emphasized how the two important Islamic values, trust and inclusivity, are necessary. In a truly peaceful world, our objective is not only to eradicate conflict but also to establish a more trusting and inclusive world community where each person is valued and respected.

Throughout the conference, worldwide concerns such as social conflict and religious extremism, humanitarian issues and universal peace, philosophy and its spiritual tradition, power, politics and the media, geo-strategies and global peace, and education and youth, have all been explored, debated and deliberated on. The speakers have driven home the importance of trust and inclusivity to the efforts of building social cohesion underlining the need for human rights protection, promoting unity and action and coherent approaches to achieving peace and non-violence in coordinated, complementary and mutually-reinforcing ways and actions.

The Menteri Besar pledged our continued commitment to fight for the Rohingya's cause and to find the ultimate solution to the issue of "the world's most persecuted minority". He went on to congratulate Universiti Sultan Azlan Shah (USAS) on the success of the WCIT which he assured will not merely be an annual affair but a long-term, commitment and campaign for global peace and non-violence.

Perhaps the greatest highlight of the Conference and the most eventful moment of the program was when the Menteri Besar announced with pride and great pleasure the approval of the Perak State Government in the setting up of the ASEAN Center for Islam, Peace and NonViolence at USAS, Kuala Kangsar. The Center is another milestone in the establishment of networks from all over the world to promote global peace, especially within the context and framework of ASEAN. The late Tan Sri Dr. Surin Pitsuwan had been requested to lead the Center as its first Chairman. Dr. Surin's illustrious credentials and dynamism would have added value to the realization of the objectives of the Center. Unfortunately, it was not meant to be. Tan Sri Dr. Surin Pitsuwan passed away from a reported heart-attack just some nine days after his return from WCIT 2017.

The honourable Menteri Besar ended his speech by quoting the late Martin Luther King, Jr., "Darkness cannot drive out darkness; only light can do that. Hate cannot drive out hate; only love can do that." He then expressed his hope for guidance along the path towards achieving global harmony and a better world of lasting peace and non-violence for our future generations.

\section{Closing Speech by the Most Honorable Deputy Prime Minister of Malaysia, YAB Dato' Seri Diraja Dr. Ahmad Zahid Hamidi}

The honorable Deputy Prime Minister expressed his sincere thanks and gratitude to the Organizing Committee for the invitation to officiate the Closing Ceremony of the Fourth World Conference on Islamic Thought and Civilization 
2017 (WCIT 2017). He also congratulated the Committee and the Perak State Government for successfully bringing together the academic conference. The presence of distinguished speakers, scholars and individuals, local and international, is testament to the importance of the conference.

The Deputy Prime Minister then continued with a quotation from the Dalai Lama, "peace does not mean an absence of conflicts, differences will always be there." Peace means solving differences through peaceful means such as dialogue, education, the dissemination of knowledge and other humane ways.

Global peace is a world without oppression, aggression, destruction and violence. Islam, as the second largest religion in the world, seeks to protect the rights of individuals in society and to promote peace through legislation, practice and doctrine. Sadly, insufficient information about true Islamic principles has led people to form misconceptions about Islam, where many believe that Islam condones terrorism.

It is very important to understand the teachings of Islam as regards peace and the concept of jihad as explained in the Qur'an. The intentional harming of an innocent person, whether Muslim or otherwise, is strongly condemned in Islam. A true Muslim would ensure peace and reject anything that causes disunity and violence. Thus, what the terrorist organizations are doing is totally against the concept of jihad in Islam and the Malaysian government has taken measures to curb terrorism, one of which is to ensure that these organizations do not receive funds and financial assistance from anyone, thus said the Deputy Prime Minister.

The Malaysian government has also set up the King Salman Centre for International Peace in Putrajaya which aims at promoting universal peace and deflecting the influence of extremism and terrorism. Global peace is not only the absence of wars but also about the provision of necessities such as food, education, jobs, housing and so on, for all.

With globalization and the whole world becoming more connected, there should be an increase in international communication and cooperation; nations working together and relying upon each other. With international cooperation and interdependence between nations, war and conflicts become undesirable. The way forward for global peace is when the survival and success of one nation benefits another.

As global peace is an urgent vision on humanity, the Deputy Prime Minister expressed his sincere hope that the conference had achieved its objectives. The journey towards global peace is still a long way away but we must keep trying because great things happen to those who do not stop trying. On behalf of the Malaysian government, he then pledged a contribution of RM3 million towards the proposed Center for Peace and Non-Violence.

On that optimistic note, the Most Honorable Deputy Prime Minister of Malaysia declared the World Conference on Islamic Thought and Civilization 2017 closed.

\section{CONCLUSION}

In this conference, a lot of informative, inspiring and motivational sessions have broadened our knowledge of current issues and raised our awareness on pressing matters that have been brought to our attention. It is hoped that the input from the conference can provoke us into making necessary and desired changes. In order to change, we need to be proactive, use our knowledge, skills and resources and, most importantly, take action. After all, action speaks louder than words.

We look forward to WCIT 2018. We welcome all academics in preparing and writing up research articles. 


\section{ACKNOWLEDGEMENT}

For the success of WCIT 2017, we would like to express our heartfelt gratitude to:

1. Duli Yang Maha Mulia Paduka Seri Sultan Perak Sultan Nazrin Muizzuddin Shah Ibni Almarhum Sultan Azlan Muhibbuddin Shah Al-Maghfur-Lah, the Sultan of Perak

2. Duli Yang Teramat Mulia Raja Muda Perak Raja Jaafar ibni Almarhum Raja Muda Musa, the Regent of Perak

3. Yang Amat Berhormat Dato' Seri Dr. Ahamd Zahid Hamidi, Deputy Prime Minister of Malaysia

4. Yang Amat Berhormat Dato' Seri DiRaja Dr. Zambry Abd Kadir, Menteri Besar of Perak

5. Tan Sri Prof. Dr. Nordin Kardi, Vice-Chancellor of USAS and Conference Chair

6. Prof. Dato' Dr. Wan Sabri Wan Yusof, Deputy Vice Chancellor of Academic and Student Affairs of USAS and Conference Director

7. Tuan Hj. Anas b Md Yusof, Deputy Vice Chancellor of Administration \& Finance of USAS and Conference Deputy Director

- All Sponsors and Partners

- All Distinguished Guests

- The Conference Secretariat

- USAS

- Last but definitely not least, our distinguished speakers and moderators

\section{REFERENCES}

Institute for Economics and Peace. (2016) Global Terrorism Index: Measuring and Understanding the Impact of Terrorism. Retrieved 4 December 2017 from http://economicsand peace.org/wpcontent/uploads/2016/11/Global-Terrorism-Index-2016.2.pdf

Institute for Economics and Peace. (2017) Global Peace Index: Measuring Peace in a Complex World. Retrieved 4 December 2017 from http://visionofhumanity.org/app/uploads/2017/06/ GPI-2017-Report-1.pdf 


\section{APPENDICES}

\section{Dignitaries Who Attended WCIT 2017}

WCIT 2017 was attended by many dignitaries. It was graced by the presence of:

- His Royal Highness Paduka Seri Sultan Nazrin Muizzuddin Shah Ibni Almarhum Sultan Azlan Muhibbuddin Shah Al-Maghfurlah, the Sultan of Perak

- His Highness Raja Ja'afar ibni Almarhum Raja Muda Musa, The Raja Muda of Perak

- The Honourable Deputy Prime Minister of Malaysia, Yang Amat Berhormat Dato' Seri DiRaja Dr. Ahmad Zahid Hamidi

- The Honourable Menteri Besar of Perak, Yang Amat Berhormat Dato' Seri DiRaja Dr Zambry Abdul Kadir.

Apart from these luminaries, WCIT 2017 was also attended by:

- Members of the Board of Directors of Kuisas Berhad

- Members of the Board of Directors of USAS

- Foreign Ambassadors to Malaysia 


\section{SPEAKERS' PROFILE}

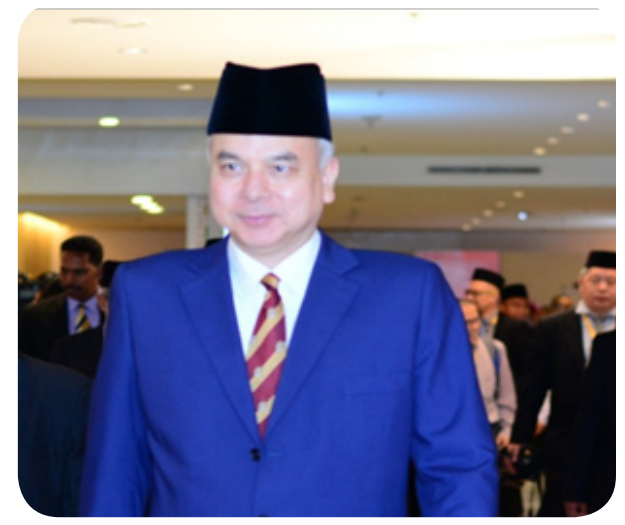

\section{SULTAN NAZRIN MUIZZUDDIN SHAH IBNI ALMARHUM SULTAN AZLAN MUHIBBUDDIN SHAH AL-MAGHFUL-LAH}

(born on 27 November 1956) is the 35th Sultan of Perak. He is currently the Deputy Yang Di-Pertuan Agong of Malaysia, elected on 14 October 2016. A highly educated man, the Sultan holds a Bachelor's degree in Philosophy, Politics and Economics from Worcester College, Oxford. He also holds a Master's degree from John F. Kennedy School of Government at Harvard University, and a $\mathrm{PhD}$ degree in Political Economy and Government from Harvard University. Sultan Nazrin is an Eminent Fellow of the Institute of Strategic and International Studies (ISIS) Malaysia, and has written articles and spoken on a wide range of issues including the role of the constitutional monarchy in Malaysia, education, Islam, ethnic relations and economic development.

\section{THE HONOURABLE DATO' SERI DR AHMAD ZAHID HAMIDI}

(born on 4 January 1953) is a Malaysian politician who has been Deputy Prime Minister of Malaysia since 2015. He has also been Minister of Home Affairs since 2013, and he previously served as Minister of Defence from 2009 to 2013. He is the Member of the Parliament of Malaysia for the Bagan Datoh constituency in Perak. The Dato' Seri holds a Bachelor of Art degree from the University of Malaya, a Master's degree in Corporate Communication and a $\mathrm{PhD}$ degree in

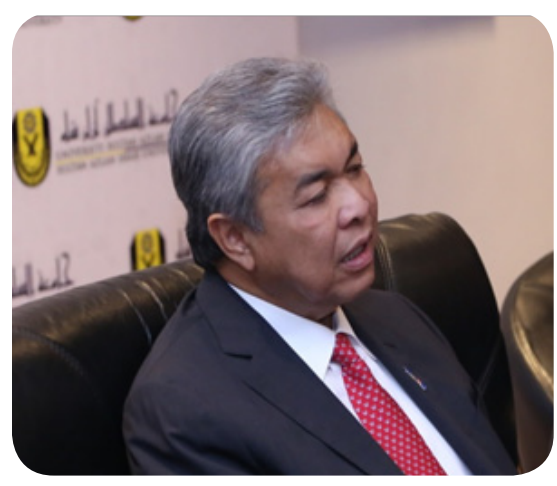
Communication Science from the Universiti Putra Malaysia.

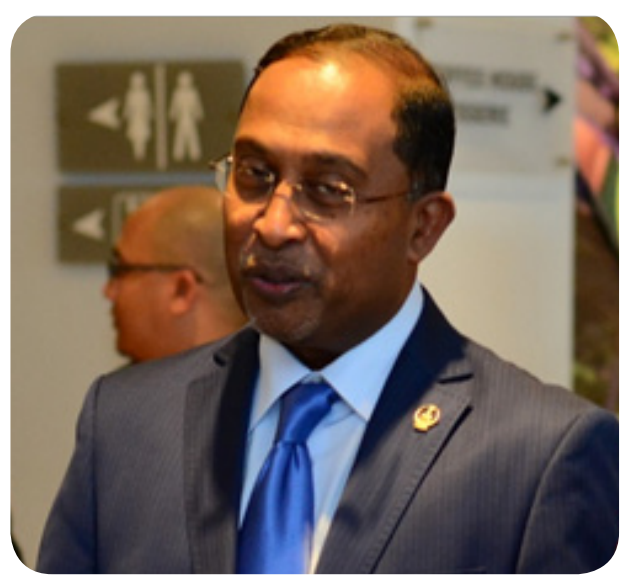

\section{THE HONOURABLE DATO' SERI DIRAJA ZAMBRY BIN ABDUL KADIR}

(born on 22 March 1962) is a Malaysian politician and the Menteri Besar of Perak since 2009. He holds a $\mathrm{PhD}$ in Political Thoughts with distinction from the Temple University Philadelphia, Pennsylvania, United States after completing his master's degree in Political Philosophy and Comparative Religion from the same university. The Dato' Seri also holds another master's degree in Islamic Thoughts from the International Islamic University Malaysia, after completing his first degree in Economics from the same institution. 


\section{TAN SRI PROF. DR. NORDIN KARDI}

The Vice-Chancellor of Universiti Sultan Azlan Shah (USAS), and the Secretary General of Asian Islamic Universities Association (AIUA). Prior to his tenure at USAS, the Tan Sri was the Vice Chancellor at Universiti Utara Malaysia and had been appointed to sit at the prestigious Za'ba Chair of Universiti Pendidikan Sultan Idris (2011 - 2013). He earned his first degree in Psychology and Economics from the Universiti Kebangsaan Malaysia, his Master of Art in Counselling from the Western Michigan University, USA, and his Ph.D in Student Personnel Services in Higher Education from the University of Hull, England.

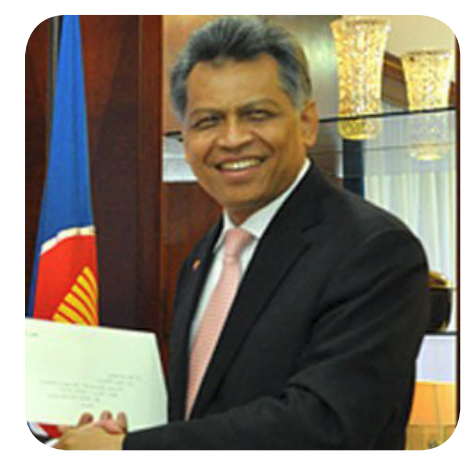

\section{TAN SRI SURIN PITSUWAN}

Tan Sri Surin Pitsuwan (born on 28 October 1949) is a native of Nakorn Sri Thammarat, Southern Thailand. He received his M.A. and Ph.D. from Harvard University, Cambridge, Massachusetts, U.S.A., in the field of Political Science and Middle Eastern Studies. In politics, Dr. Surin was a Deputy Leader of the Democrat Party, Thailand. He also served on the National Reconciliation Commission (NRC), charged with bringing peace and security back to Thailand.

\section{SHAYKH MUHAMMAD YAHAYA AL-NINOWY}

Shaykh Dr. Muhammad bin Yahya Al-Husayni An-Ninowy is a Syrian-born Islamic Scholar who also holds a Bachelor's Degree in Mircobiology from the University of Illinois and a Doctor of Medicine. He has authored many books in the science of Tawheed, Hadith, and Usul, some of which are being translated into English and published.

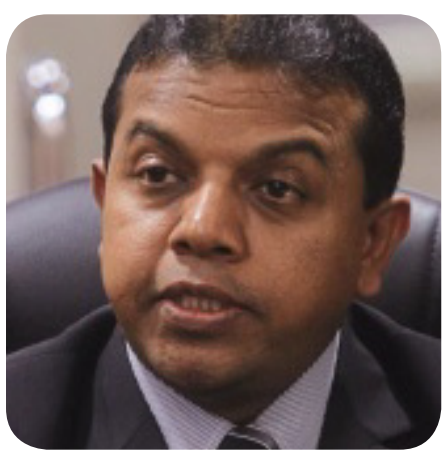

\section{YDH DATO' AYOB KHAN MYDIN PITCHAY}

Dato' Ayob Khan Mydin Pitchay, Senior Assistant Commissioner of the Royal Malaysian Police Force is now the Head of the Counter Terrorism Division since February 2014. He first joined the Royal Malaysian Police Force in 1991 after completing his bachelor's degree in Business Administration. He also holds a master's degree in Informational Technology from a renowned university. He has many years of experience in combating terrorism in Malaysia. 


\section{PROF. BRUCE LAWRENCE}

Bruce Lawrence is a distinguished professor at Duke University, USA, since 1971. He is a graduate of Princeton University with a Master of Divinity from Episcopal Divinity School in Cambridge and obtained his Ph.D in History of Religions from Yale University. His area of interest covers the study of culture and language, religions and practices.


\section{PROF. DATO' DR. AHMAD MURAD MERICAN}

Prof. Datuk Dr. Ahmad Murad Mohd Noor Merican holds a MA in Mass Communication and a Ph.D in the History and Philosophy of Science from University Malaya. He is the faculty member of the Centre for Policy Research and International Studies (CenPRIS), University Sains Malaysia in Penang and a professor at the Department of Management and Humanities at University Technology Petronas.

\section{PROF. DR. KAMARULNIZAM ABDULLAH}

Prof. Dr. Kamarulnizam Abdullah holds a Ph.D in International Politics from University of Lancaster. He has published numerous works throughout his years as an academician. Among his latest publications are; "Conceptualising Jihad among Southeast Asia's Radical Salafi Movement", "Malaysia's Peacekeeping Operation Contribution" and "The Death of Osama: The View from Malaysia". He is currently an editorial member of the Scopus Indexed Journal of Human Security and Journal of International Studie's.
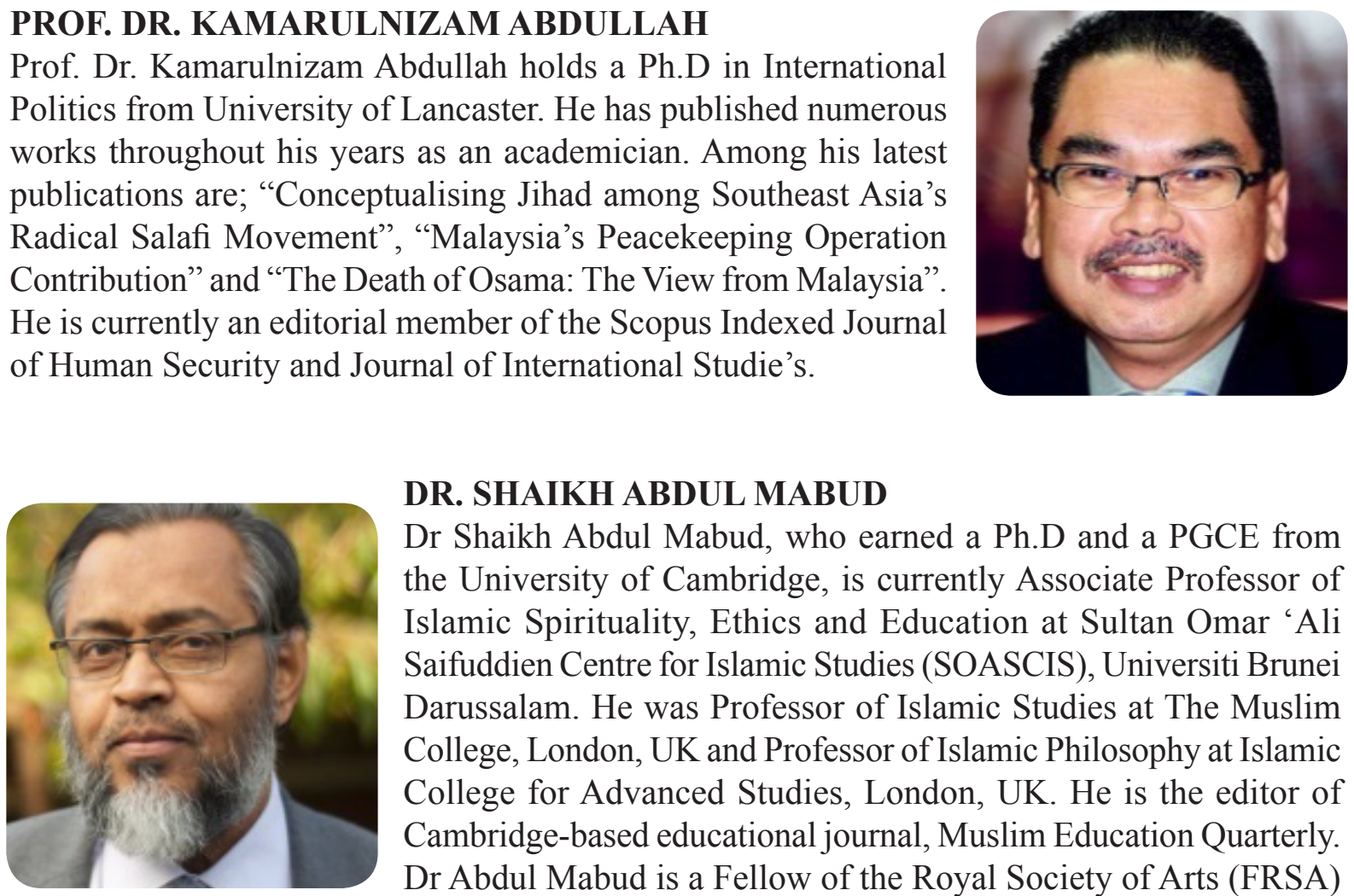

\section{DR. SHAIKH ABDUL MABUD}

Dr Shaikh Abdul Mabud, who earned a Ph.D and a PGCE from the University of Cambridge, is currently Associate Professor of Islamic Spirituality, Ethics and Education at Sultan Omar 'Ali Saifuddien Centre for Islamic Studies (SOASCIS), Universiti Brunei Darussalam. He was Professor of Islamic Studies at The Muslim College, London, UK and Professor of Islamic Philosophy at Islamic College for Advanced Studies, London, UK. He is the editor of Cambridge-based educational journal, Muslim Education Quarterly. Dr Abdul Mabud is a Fellow of the Royal Society of Arts (FRSA) and a Life Fellow of Cambridge Philosophical Society. 


\section{PROF. DR. M. A. MUQTEDAR KHAN}

Dr. Muqtedar Khan is an Associate Professor in the Department of Political Science and International Relations at the University of Delaware. He earned his Ph.D. in International Relations, Political Philosophy, and Islamic Political Thought, from Georgetown University in May 2000. He founded the Islamic Studies Program at the University of Delaware and was its first Director from 2007-2010. He is a Fellow with the Institute for Social Policy and Understanding. He has lectured in North America, East Asia, Middle East and Europe.

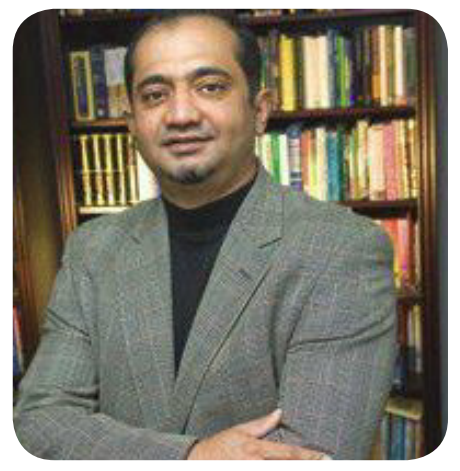

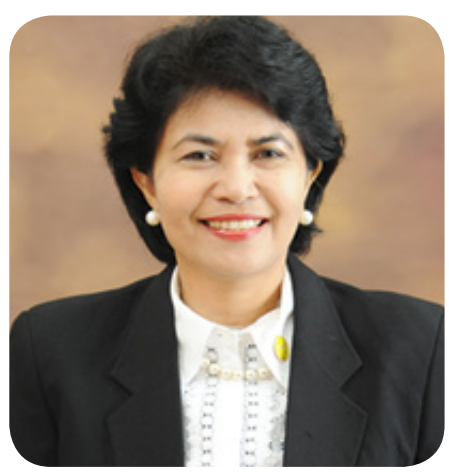

\section{PROF. DR. DEWI FORTUNA ANWAR}

She is a Professor and the Deputy Secretary for Political Affairs to the Vice President of Indonesia and a Research Professor at the Indonesian Institute of Sciences (LIPI). She was the Deputy Secretary for Political Affairs from 2010-2015 and from 2015 to 2017 as Deputy for Government Policy Support to the Vice President of the Republic of Indonesia. She is also the Chair of the Institute for Democracy and Human Rights at the Habibie Centre, and a member of the Board of Advisors, the Institute for Peace and Democracy, the Bali Democracy Forum.

\section{DR. CHANDRA MUZAFFAR}

Dr. Chandra Muzaffar is the President of the International Movement for a Just World (JUST). Chandra is also the Chairman of the Board of Trustees of the 1Malaysia Foundation. He has published extensively on civilizational dialogue, international politics, religion, human rights and Malaysian society. The author and editor of 31 books in English and Malay, among his most recent are "A World in Crisis: Is There a Cure?" and "Critical Concerns from East to West."
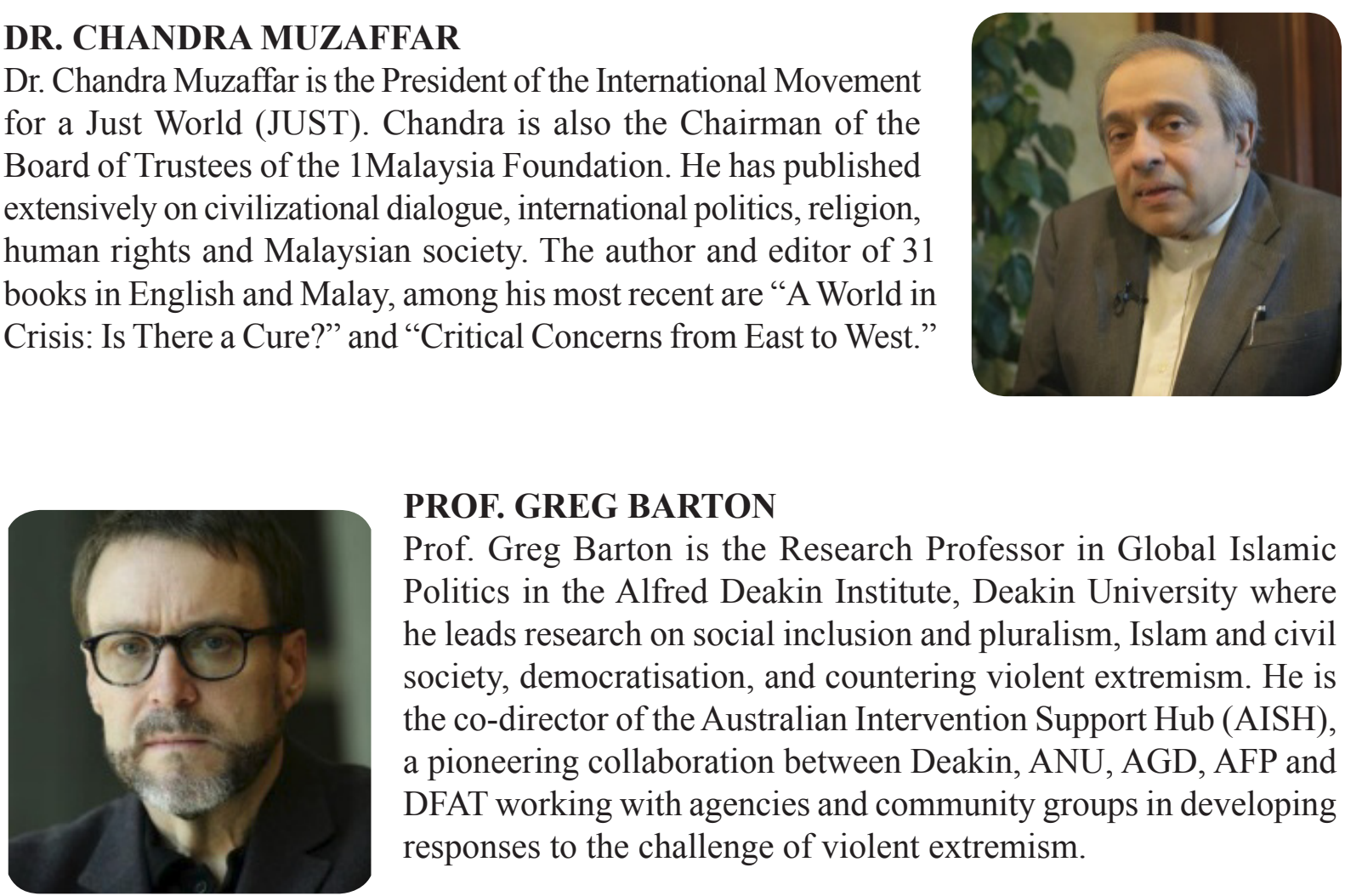

\section{PROF. GREG BARTON}

Prof. Greg Barton is the Research Professor in Global Islamic Politics in the Alfred Deakin Institute, Deakin University where he leads research on social inclusion and pluralism, Islam and civil society, democratisation, and countering violent extremism. He is the co-director of the Australian Intervention Support Hub (AISH), a pioneering collaboration between Deakin, ANU, AGD, AFP and DFAT working with agencies and community groups in developing responses to the challenge of violent extremism. 


\section{PROF. DR. AHMAD FAUZI HAMID}

He is a Professor of Political Science, School of Distance Education, Universiti Sains Malaysia (USM). He earned his $\mathrm{PhD}$ in Politics from the University of Newcastle upon Tyne, United Kingdom, in 1998. He is a member of the Editorial Board for Kajian Malaysia: Journal of Malaysian Studies (since January 2014), member of the Editorial Board for Kemanusiaan: The Asian Journal of Humanities (since June 2014) and the member of International Advisory Board of Islamic Studies (Islamabad) (September 2006).
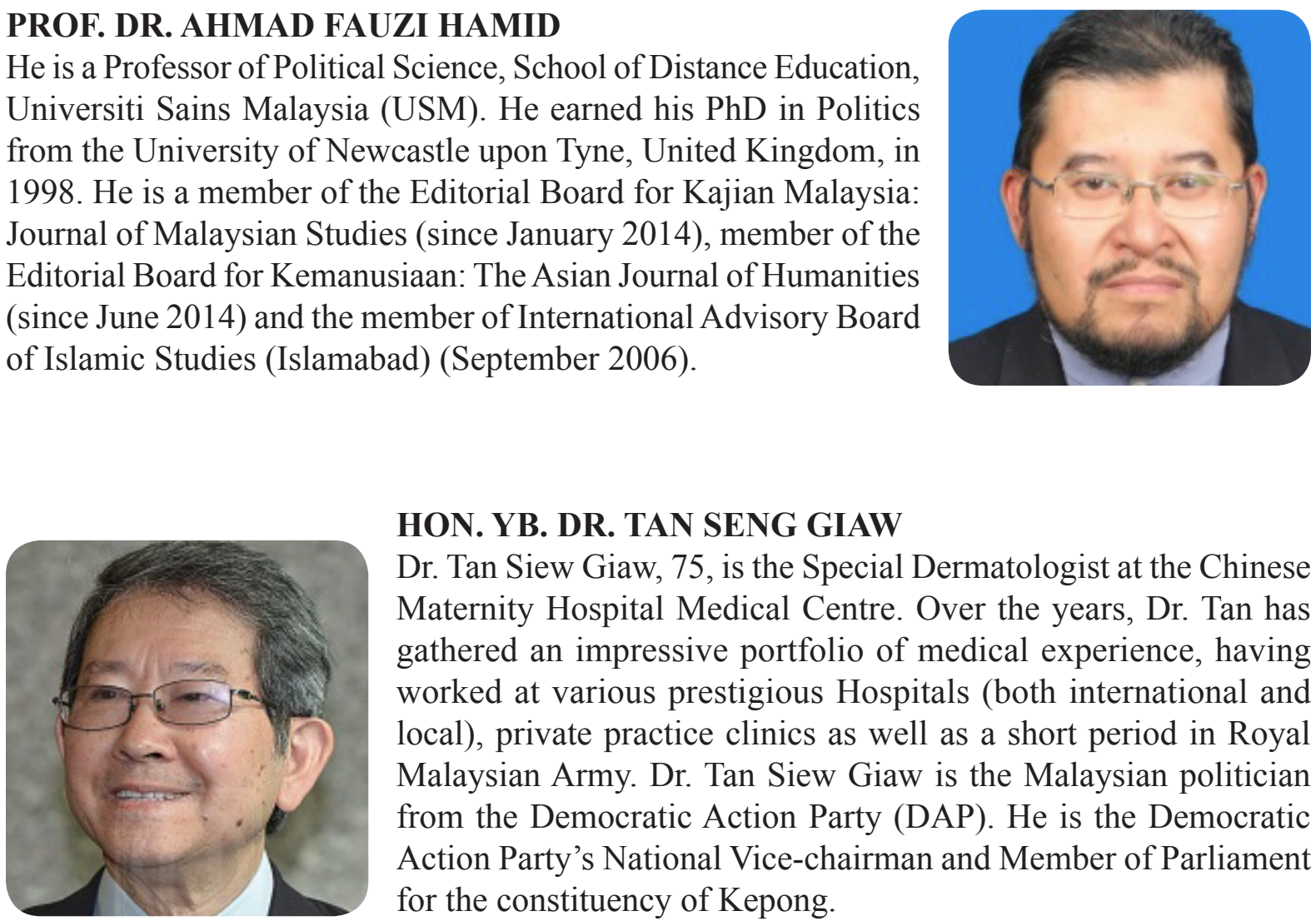

\section{HON. YB. DR. TAN SENG GIAW}

Dr. Tan Siew Giaw, 75, is the Special Dermatologist at the Chinese Maternity Hospital Medical Centre. Over the years, Dr. Tan has gathered an impressive portfolio of medical experience, having worked at various prestigious Hospitals (both international and local), private practice clinics as well as a short period in Royal Malaysian Army. Dr. Tan Siew Giaw is the Malaysian politician from the Democratic Action Party (DAP). He is the Democratic Action Party's National Vice-chairman and Member of Parliament for the constituency of Kepong.

\section{COL. (RET.) ANN WRIGHT}

Col. (Ret.) Ann Wright (born in 1947) grew up in Bentonville, Arkansas, and attended the University of Arkansas, where she earned a Master's and a Law degree. She also has a Master's degree in National Security Affairs from the US Naval War College. For 13 years, after Wright was released from active duty, she joined the State Department. For the next 16 years, she served as a foreign diplomat in countries such as Nicaragua, Somalia, Uzbekistan, and Sierra Leone.
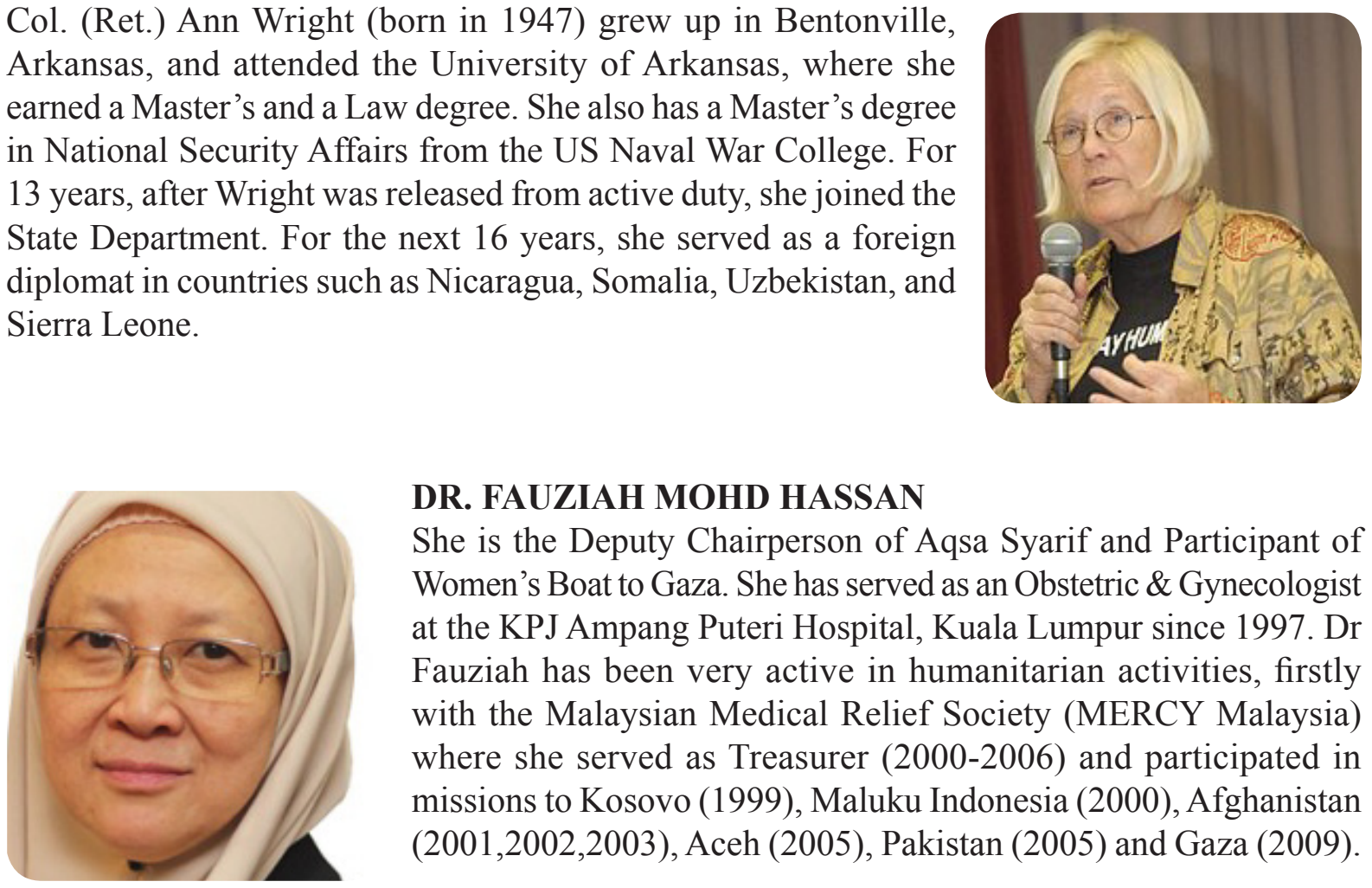

\section{DR. FAUZIAH MOHD HASSAN}

She is the Deputy Chairperson of Aqsa Syarif and Participant of Women's Boat to Gaza. She has served as an Obstetric \& Gynecologist at the KPJ Ampang Puteri Hospital, Kuala Lumpur since 1997. Dr Fauziah has been very active in humanitarian activities, firstly with the Malaysian Medical Relief Society (MERCY Malaysia) where she served as Treasurer (2000-2006) and participated in missions to Kosovo (1999), Maluku Indonesia (2000), Afghanistan (2001,2002,2003), Aceh (2005), Pakistan (2005) and Gaza (2009). 


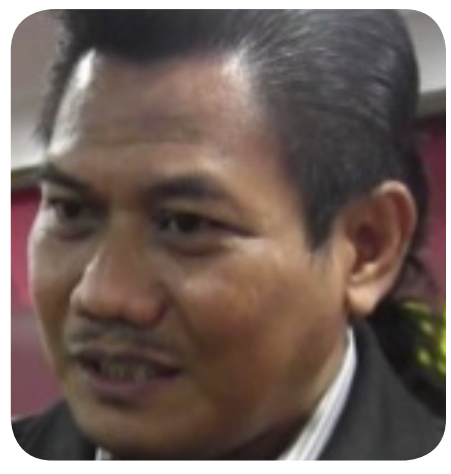

\section{DR. MOHD HELMI IBRAHIM}

Dr. Helmi Ibrahim is one of the important leaders in Muslim Care Malaysia, a non-governmental organization. His position is as the Exco of Health II where it is believed that this organization carries out welfare and humanitarian projects. They will help all kind of contributors to deliver their contribution to the needy. Plus, he is also responsible as the executive director of The Asean Rohingya Centre (ARC). The ARC has set up a Rohingya Consensus Council which will be responsible for curbing the spread of extreme ideologies. Besides, this centre would also look after the welfare of the Rohingya community and implement any decision agreed to by the council's leadership.

\section{PROF. DATO' DR. NORAZAH MOHD. NORDIN}

Prof. Dr Norazah Nordin is currently the Dean of the Faculty of Education, Universiti Kebangsaan Malaysia (UKM). She is a professor in ICT in Education. She is a very active researcher and has contributed on many educational researches. Her research areas include Massive Online Open Courses, Mobile Learning, Integrating ICT in Education and Lifelong Learning, and Instructional Design in Online Learning. At the national level, she is a committee member of the Critical Agenda Project (CAP) (E-Learning), Ministry of Education, Malaysia and also a member of the Council of Malaysian

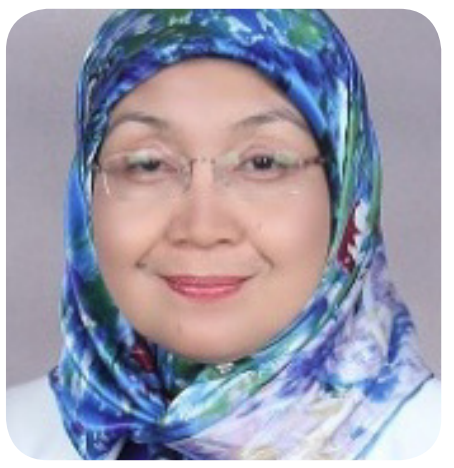
Public Higher Education Institutions e-Learning Coordinators.

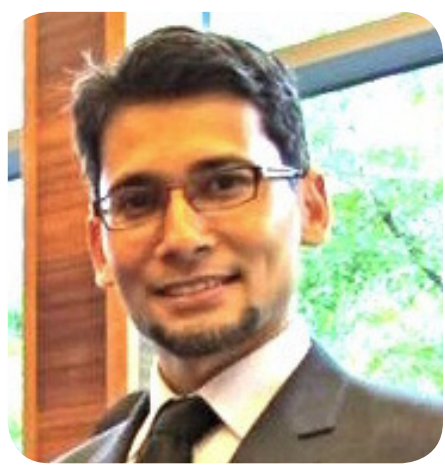

\section{DR. SYED MUHAMMAD KHAIRUDIN ALJUNIED}

Dr Khairudin Aljunied is an Associate Professor at the Faculty of Arts and Social Sciences, National University of Singapore (NUS). He received his BA and MA in History from the National University of Singapore in 2003 and completed his doctorate at the School of Oriental and African Studies, London in 2008. Dr Khairudin has studied and conducted research in countries such as the Philippines, Indonesia, Malaysia, Australia, Netherlands and the United Kingdom. 


\section{TAN SRI RAZALI ISMAIL}

Tan Sri Razali Ismail is a distinguished Malaysian diplomat. He holds a Bachelor of Arts degree with Honours in literature and the humanities from Universiti Malaya and an Honorary Doctorate from Universiti Kebangsaan Malaysia. In the past, he usually headed Malaysian diplomatic delegation to various regional and international bodies such as ASEAN and the Non-Aligned Movement. He retired from government in 1998, after 10 years as Malaysia's Permanent Representative to the United Nations. He is also the Chair of Cypark Resources Berhad and Allianz Malaysia Berhad as well as the Pro-Chancellor of Universiti Sains Malaysia. He was appointed

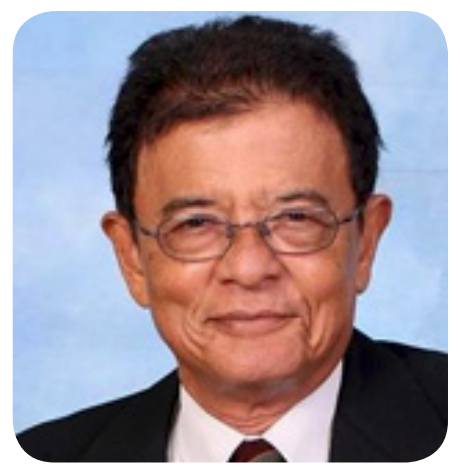
as the Chairman of the Human Rights Commission of Malaysia (SUHAKAM) in June 2016 for the term 2016-2019.

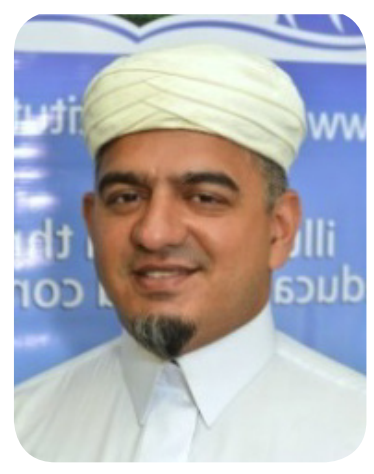

\section{HAFIZ MAHMOOD KHATIB}

Hafiz Advocate Mahmoud Khatib is the grandson of the late Shaykh Abubakr Khatib of the Jaami' Masjid Gray Street in Durban. He completed his Hifz-ul Qur'an under his illustrious father and studies Arabic and Islamic Studies at the Islamic College of Southern Africa and at the University of Durban-Westville. He completed his LLB and practice as a Barrister for many years. He contributed to the establishment of Muslim Personal Law and serves as the President of Masjidul Quds, and a Trustee of Madina Institute.

\section{PROF. DR. AILEEN SAN PABLO-BAVIERA}

She is a professor at the Asian Center, University of the Philippines Diliman. She used to be a Dean from 2003 to 2009. Apart from that, she also has a visiting professor appointment at the University of Malaya. She earned her Ph.D in Political Science (focusing on Comparative Politics and International Relations) in 2003. Her areas of expertise include Philippine foreign policy, PhilippinesChina relations, South China Sea disputes, Association of Southeast Asian Nations (ASEAN) affairs, and United States (US) foreign policy. She specialized in contemporary China,Southeast Asia-China relations, Asia Pacific security, with secondary interests in regional

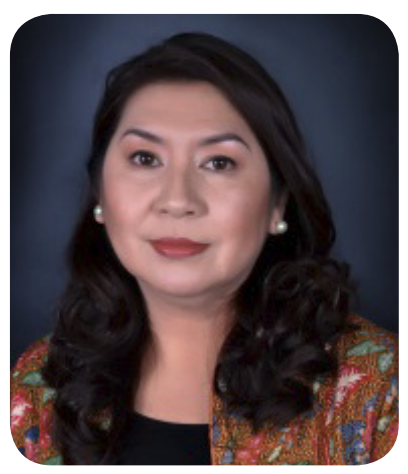
integration and Asian civil society. Aside from her academic work, she is the founding president of Asia Pacific Pathways to Progress Foundation, Inc. a non-profit organization established in 2014 to support projects and programs for international dialogue, cooperation, and cultural understanding. In 2015, she was a recipient of the U.P. Alumni Association Distinguished Alumnus Award for her work in international strategic studies. 


\section{Tribute to Surin Pitsuwan}

\section{Farewell Surin Pitsuwan, a visionary leader of ASEAN}

The Jakarta Post · 5 Dec 2017 . Dewi Fortuna Anwar The writer is a research professor at the Center for Political Studies, Indonesian Institute of Sciences (P2P-LIPI), Jakarta, and distinguished visiting professor at the S. Rajaratnam School of International Studies, Nanyang Technologic

When I first heard the news of Surin Pitsuwan's death on Thursday, Nov. 30 from a friend, my first reaction was disbelief. After reading the link to the news in the Bangkok Post I was shocked and unbearably saddened. I regard Khun Surin, as he was known, as a mentor and a good friend, whose compassion and vision for a more humane global and regional order I have always admired and aspired to emulate.

My terrible shock at hearing of his sudden passing, however, was not only because it was so unexpected but because only a week earlier we had both attended the World Conference on Islamic Thought 2017 organized by Sultan Azlan Shah University in Ipoh, Malaysia. On Oct. 5-6 we both participated in the second East Asia-West Asia Seminar in Amman, Jordan.

Dr. Surin Pitsuwan was truly a man for all seasons. He was a learned scholar of Islam, an expert on international relations, a distinguished politician in Thailand and a renowned diplomat. He served as one of Thailand's most distinguished foreign ministers (1997-2001) and ASEAN secretary general (2008-2012).

Pitsuwan was a true intellectual and an analytical thinker, but what made him truly outstanding was that he was always an inspirational speaker with remarkable facility with words, able to speak about complex issues in ways that were easily understood by his listeners.

Overall of course, he was always gracious, charming and generally a very nice human being, who remained humble despite his many accomplishments.

The theme of the above conference was global peace and Pitsuwan was one of the distinguished speakers at the plenary opening session on Nov. 20, and his delivery was classic Surin. Drawing from his education in his family's Islamic pondok or boarding school in Nakhon Si Thammarat, Thailand and in Egypt, Khun Surin was able to recite verses from the Quran and he quoted the Hadiths about the true meaning of Islam as a religion of peace as exemplified by its very name, and the Islamic greeting, "Assalamulaikum," or "Peace be with you."

Pitsuwan talked knowledgably about the teachings of Prophet Muhammad and the ideals of Islam as a blessing for the whole world, Rahmatanlil Alamin, and then conveyed 
his criticisms and concerns about how the name of Islam has lately been misused and abused by a small group of extremists and terrorists, who have threatened global peace and our common humanity.

That evening the two of us, moderated by Tan Sri Razali Ismail, a former Malaysian ambassador to the United Nations, talked about conflicts and achieving peace in Southesat Asia. Khun Surin reminisced about his time as Thai foreign minister and how president BJ Habibie, in the aftermath of the ballot in East Timor in 1999, called on Thailand and the other ASEAN countries to send troops as peacekeepers to restore peace in East Timor.

This was the first time that an ASEAN member state had called on fellow ASEAN members to send in peacekeepers. Indonesia would later also invite ASEAN and the European Union to monitor the implementation of the Helsinki Peace Agreement that ended the drawn out conflict in Aceh in 2005.

Pitsuwan belonged to the second generation of ASEAN leaders who had the vision to transform this regional organization from its minimalist beginning to its true potential as an ASEAN Community that is people-oriented, people-driven and people-centered. When it was first established, ASEAN in 1967 was envisaged as an intergovernmental association aimed at promoting good neighborly relations with limited substantive cooperation.

While the principles of sovereignty, equality and non-intervention in each other's domestic affairs have been the basis of international relations since the emergence of the Westphalian states in 1648 and enshrined in the 1948 UN Charter, ASEAN seems to have made these principles its very own immutable rules.

Pitsuwan, from his time as Thailand's deputy foreign minister and later foreign minister, was among visionary leaders of ASEAN who understood that time has changed, that globalization has blurred the divisions between the internal and external, making all countries and peoples within a region and between different regions interconnected with one another. We are now living in a post-Westphalian states world.

Khun Surin took the lead in persuading ASEAN to push the military junta in Myanmar to ease its tight political control and release its political prisoners, including the Nobel Peace Prize recipient Aung San Suu Kyi.

While many other ASEAN foreign ministers remained hesitant, he promoted the idea of ASEAN's "constructive engagement" with Myanmar, later softened to "flexible engagement" or "enhanced interaction", arguing that happenings within Myanmar had an impact on ASEAN as a whole.

During his tenure as ASEAN secretary general Pitsuwan worked hard to transform the image of ASEAN as a purely government driven organization and make it more responsive to the needs of the peoples. Although the ASEAN Charter, signed in 2007, contained various principles which would make ASEAN into a truly people-centered and people-driven regional community, it was not easy for Pitsuwan to change ASEAN's culture.

He was often invited to speak in forums organized by civil society groups where he would underline the need for ASEAN countries to strive for democracy and respect human 
rights, but at times he was rebuked for his activism by the representatives of ASEAN member states.

ASEAN's journey to become a prosperous and truly sharing and caring community as well as a political and security community in which there is not only peace between states, but also peace within states, is still long and fraught with various dangers and obstacles. Khun Surin's untimely passing has deprived us of a great and visionary regional leader and ASEAN's most prominent spokesman. Rest in Peace Pak Surin. We will nurture your legacy. 


\section{WORTHY QUOTES}

Some Worthy Quotations From The Conference

"Leading proponents of peace have said that peace is not merely the absence of war. I would add that peace should also be the absence of want and fear. It is religious freedom and respect for different cultures. It is the acceptance, understanding and celebration of diversity in all its many forms."

Paduka Seri Sultan Nazrin Muizzuddin Shah Ibni Almarhum Sultan Azlan Muhibbuddin Shah Al-Maghfurlah, the Sultan of Perak.

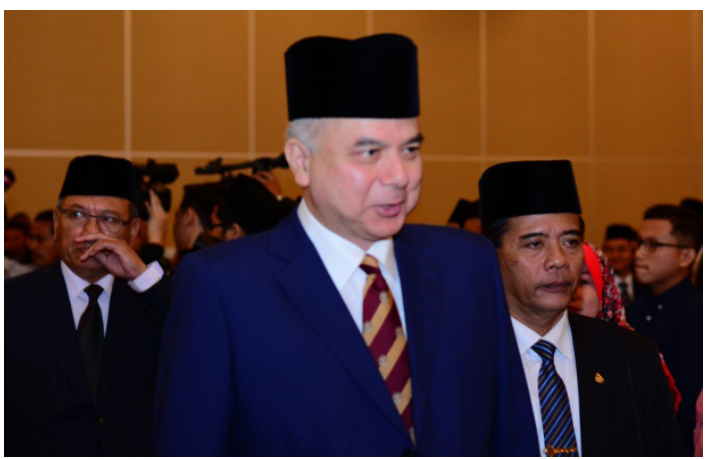

His Royal Highness the Sultan of Perak.

"Peace does not mean an absence of conflicts, differences will always be there."

The Dalai Lama (Quoted by the Honourable Dato' Seri Dr. Ahmad Zahid Hamidi, Deputy Prime Minister of Malaysia).

"The intentional harming of an innocent person, whether Muslim or otherwise, is strongly condemned in Islam. A true Muslim would ensure peace and reject anything that causes disunity and violence."

The Honourable Dato' Seri Dr. Ahmad Zahid Hamidi, Deputy Prime Minister of Malaysia.

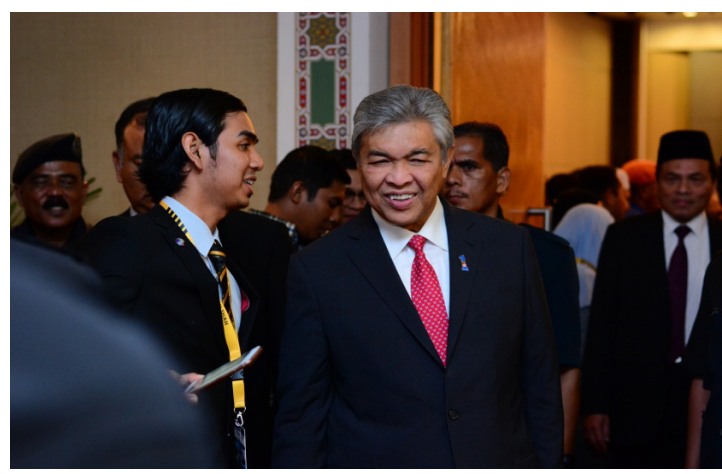

The Honourable Deputy Prime Minister of Malaysia.

"Darkness cannot drive out darkness; only light can do that. Hate cannot drive out hate; only love can do that."

Martin Luther King (Quoted by the Honourable Y.A.B. Dato' Seri DiRaja Dr. Zambry bin Abd Kadir, the Menteri Besar of Perak).

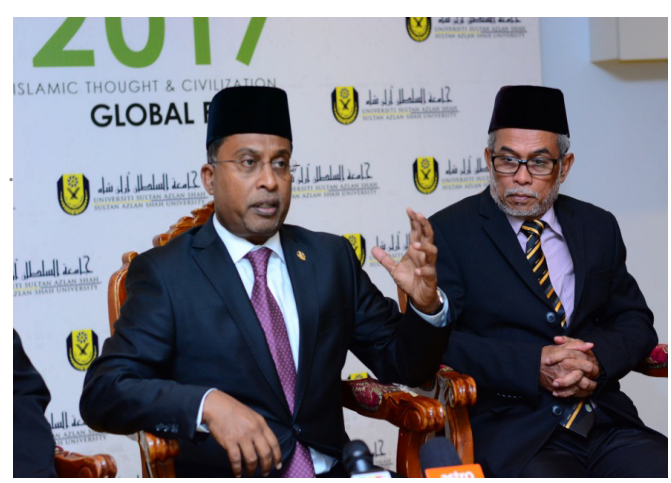

The Honourable Menteri Besar of Perak.

"The youth of today are NOT the future generation. They are the CURRENT generation."

- Sheikh Hafiz Mahmood Khatib: 
GJAT | DECEMBER 2017 | VOL 7 ISSUE 2 | 40

ISSN : 2232-0474 | E-ISSN : 2232-0482

www.gjat.my

"A person who doesn't know their history, do not have an identity, and people without identity, will fall for anything and everything."

- Malcolm X (Quoted by Dr. Khairuddin AlJunied).

“........The explosion of knowledge and implosion of wisdom."

- Prof D.S. Kothari (Quoted by Dr. Khairuddin AlJunied).

"The illiterate of the $21^{\text {st }}$ century are not those who cannot read but those who cannot learn, relearn and unlearn."

- Alvin Toffle (Quoted by Professor Dato’ Dr. Norazah Mohd. Nordin).

"Knowledge is the life of the mind."

- Abu Bakr as-Siddiq (Quoted by Professor Dato’ Dr. Norazah Mohd. Nordin).

"We must not personalise the content and context of history and we must not dehumanize it either."

- Tan Sri Razali Ismail.

“A text out of context is a pretext."

Unknown (Quoted by Sheikh Muhammad Yahaya Al-Ninowy).

"If you're good only to those who are good, then what good are you?"

Sheikh Muhammad Yahaya Al-Ninowy. 


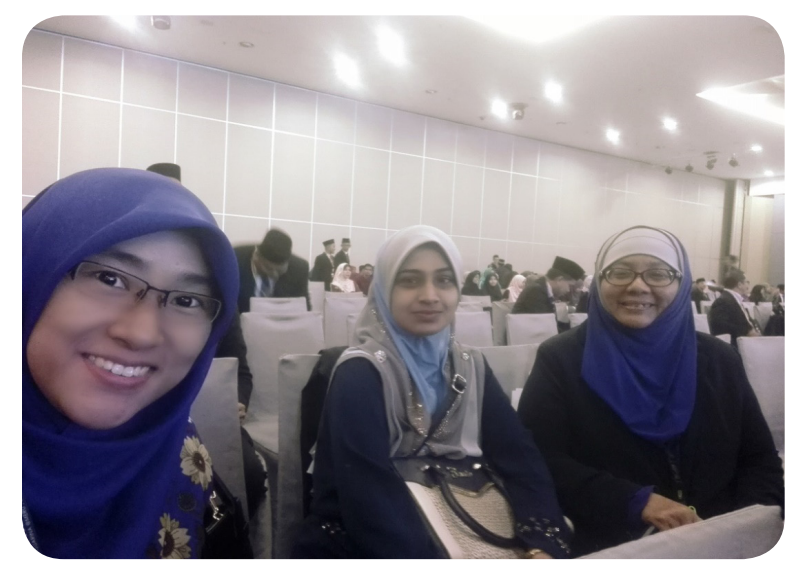

The GJAT Editorial Team

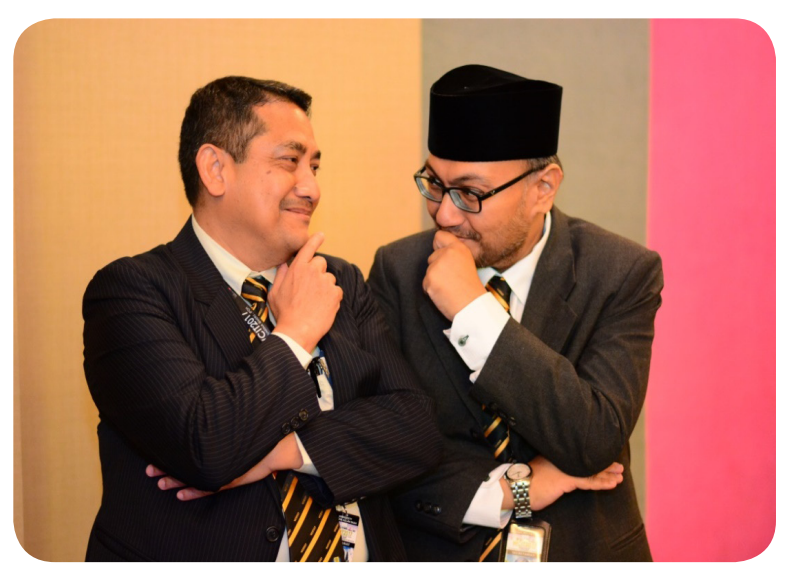

Aren't we cute?

Grand Appearance of VVIPs

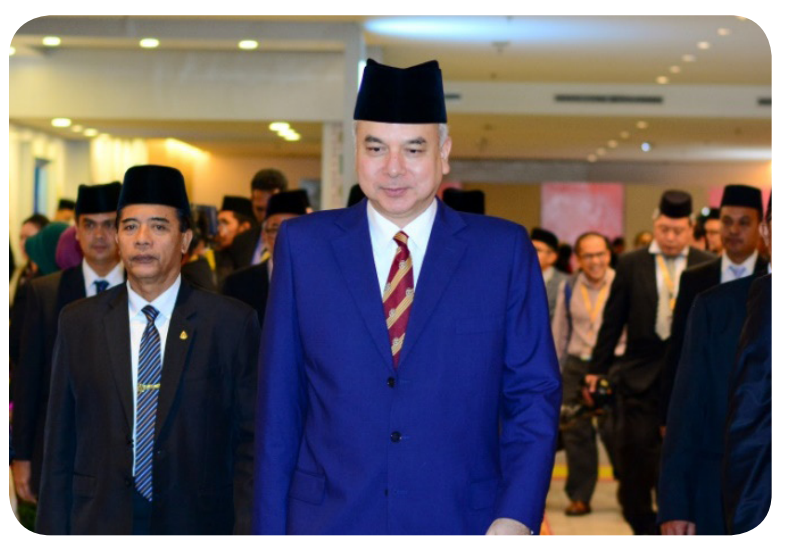

HRH the Sultan of Perak!

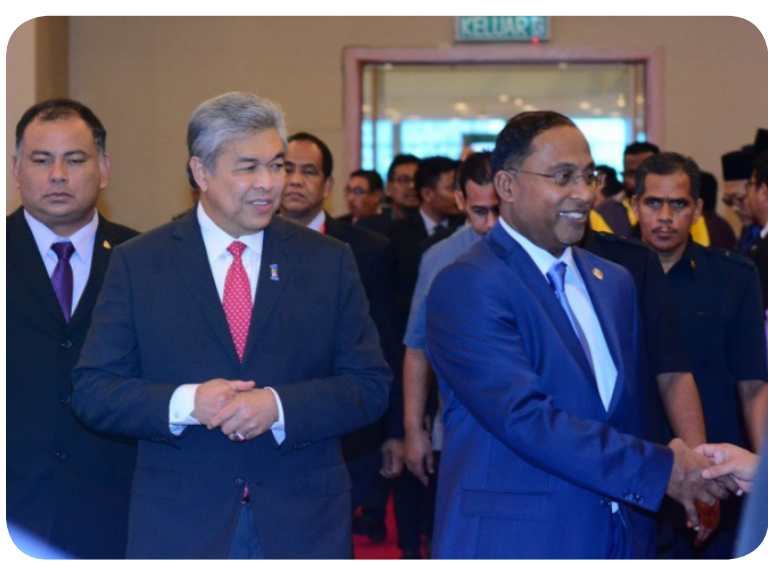

Welcome! Welcome! The Deputy Prime Minister of Malaysia, flanked by the Menteri Besar of Perak

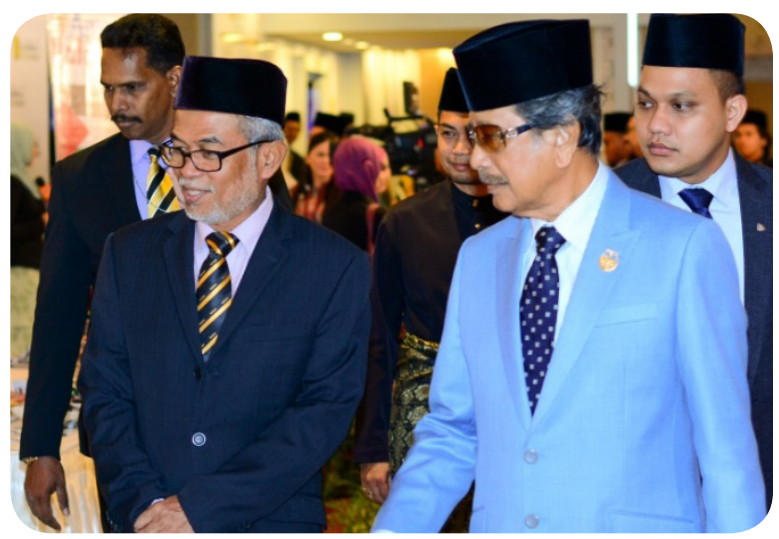

Hmmm...interesting! The Raja Muda of Perak having his light moments with The ViceChancellor of USAS, Tan Sri Prof. Dr. Nordin Kardi

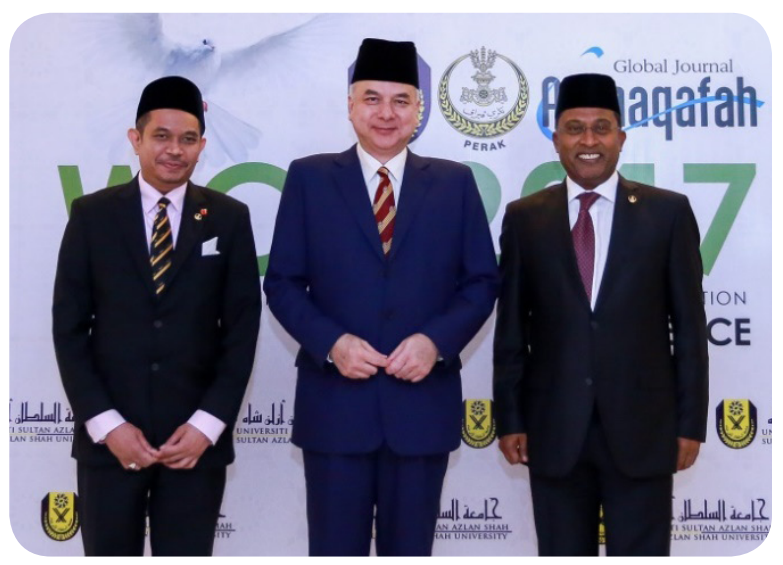

“The Philosopher King” flanked by The Menteri Besar of Perak, YAB Dato' Seri Diraja Dr. Zambry bin Abd Kadir and Dato' Dr. Afifi alAkiti, KFAS fellow in Islamic Studies at the Oxford Centre for Islamic Studies 


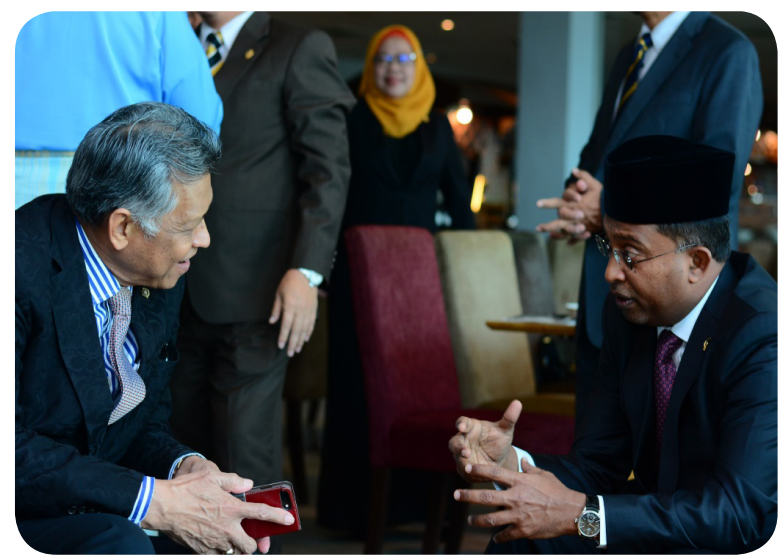

Two great minds. Defining moments with the late Surin Pitsuwan

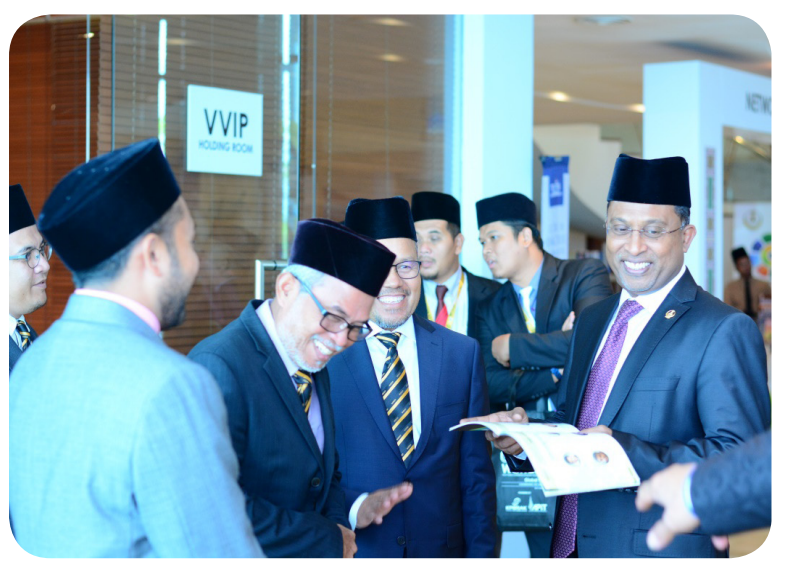

Laugher creates peace! It's contagious too. Wonder what went on!

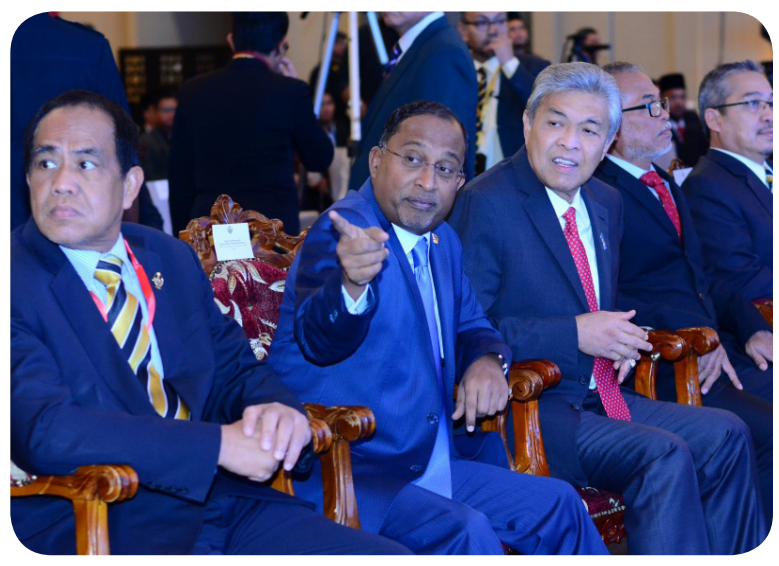

Look! Over there! Something must have gotten the undivided attention of the Menteri Besar and the Deputy Prime Minister

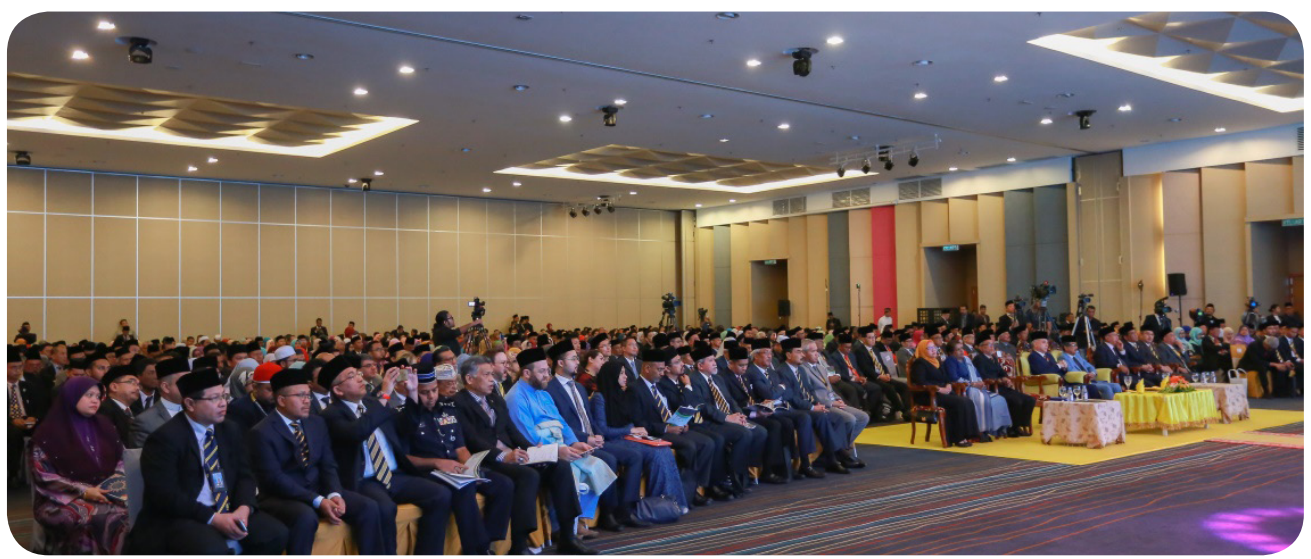

The Full House Crowd

Fascinating... 


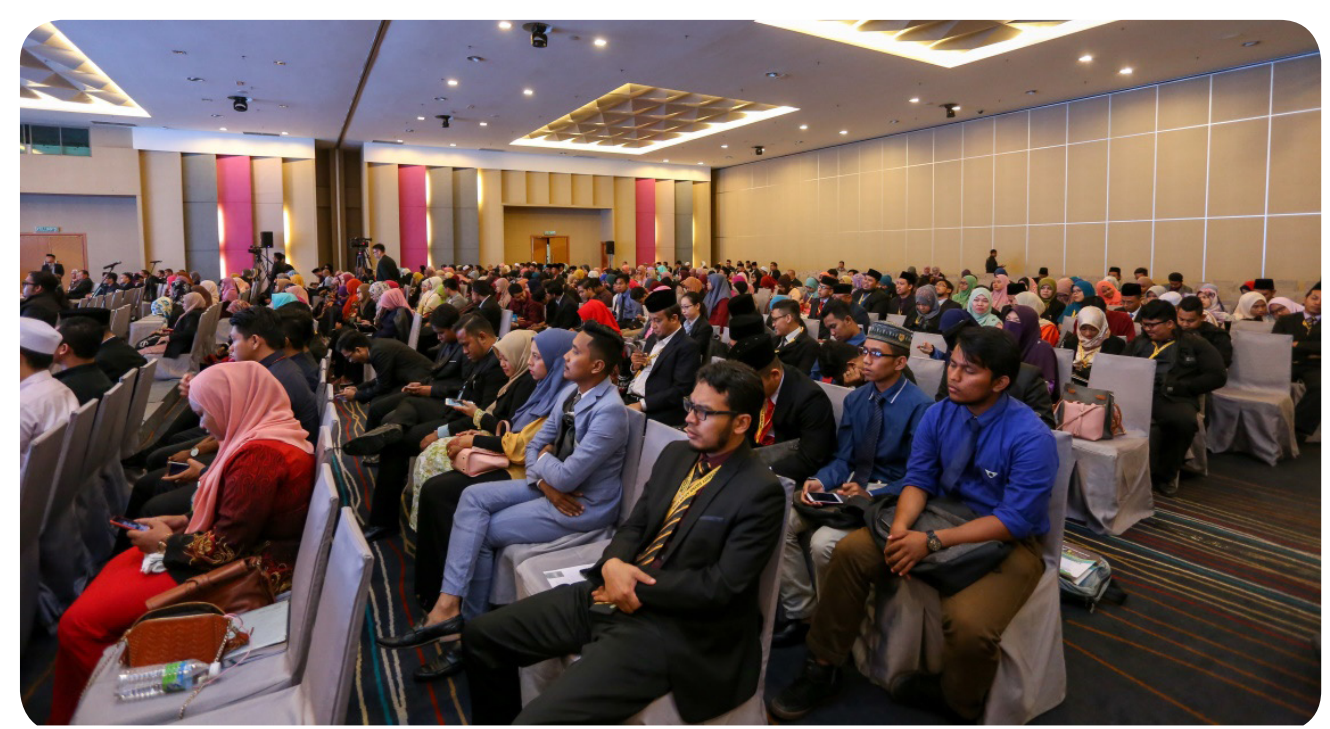

We didn't know the conference is such fun!

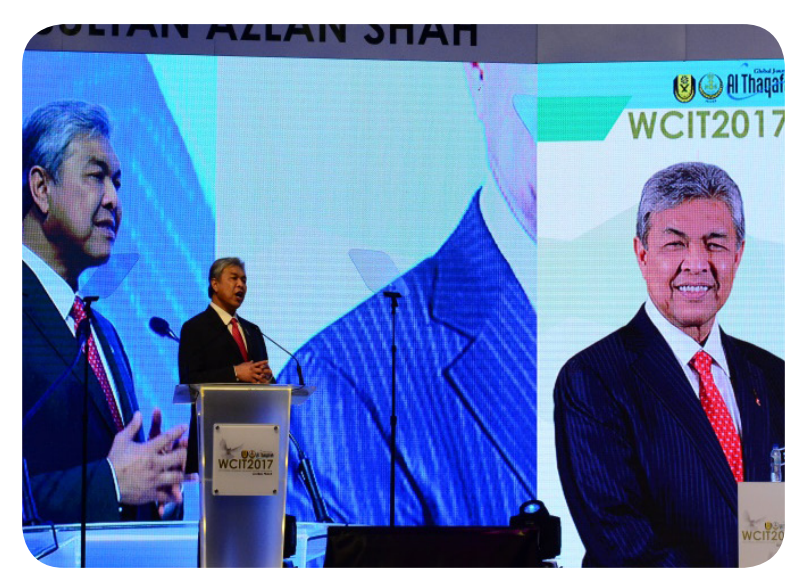

A grand closing

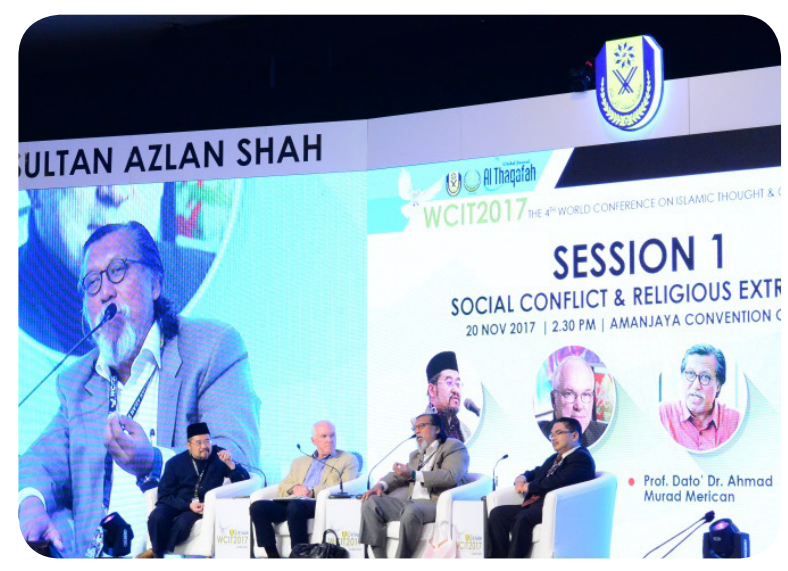

Towards conflict resolution

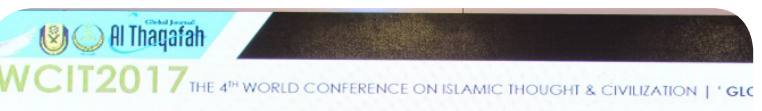

SESSION 2

PHILOSOPHY \& ITS SPIRITUAL TRADITION 20 NOV 2017 | 4.00 PM | AMANJAYA CONVENTION CENTRE 1

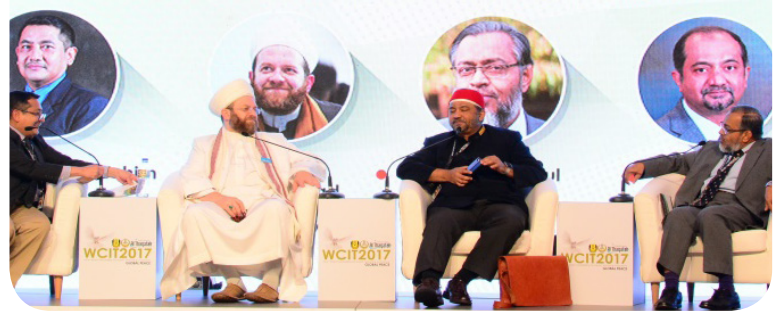

A meeting of the minds

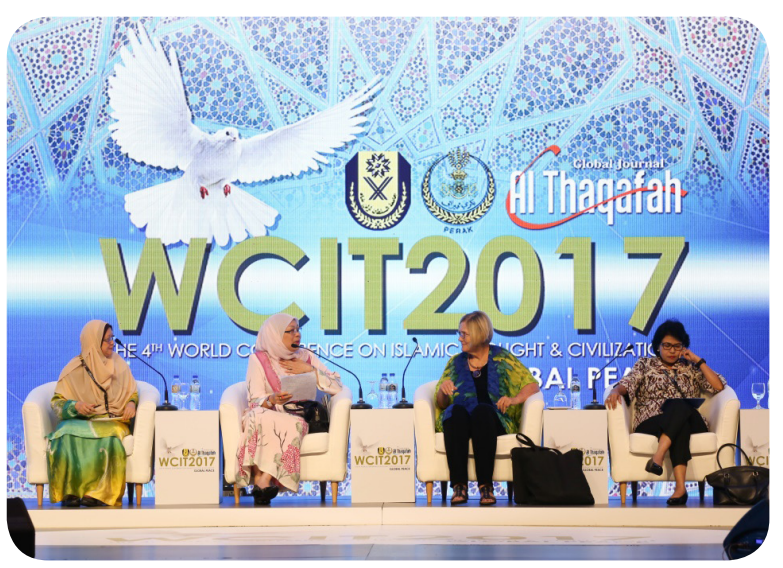

The hands that rock the cradle, rock the world! 


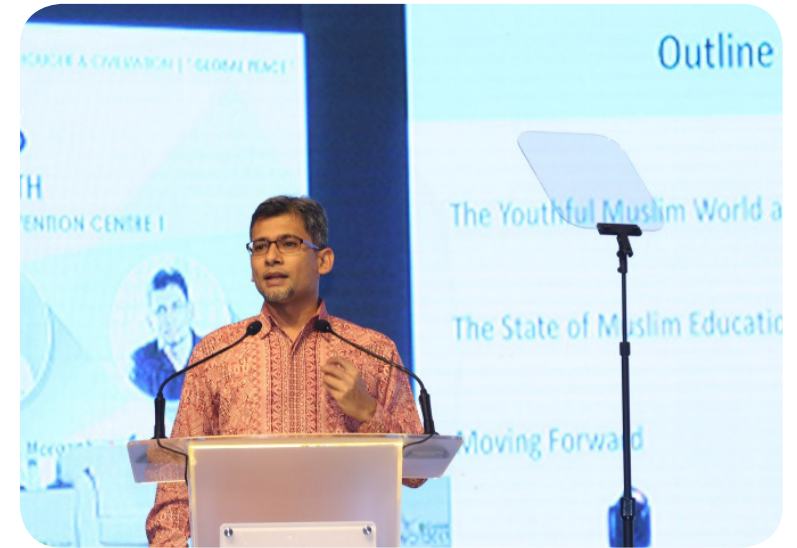

Let's cure our youth of "fedupism"

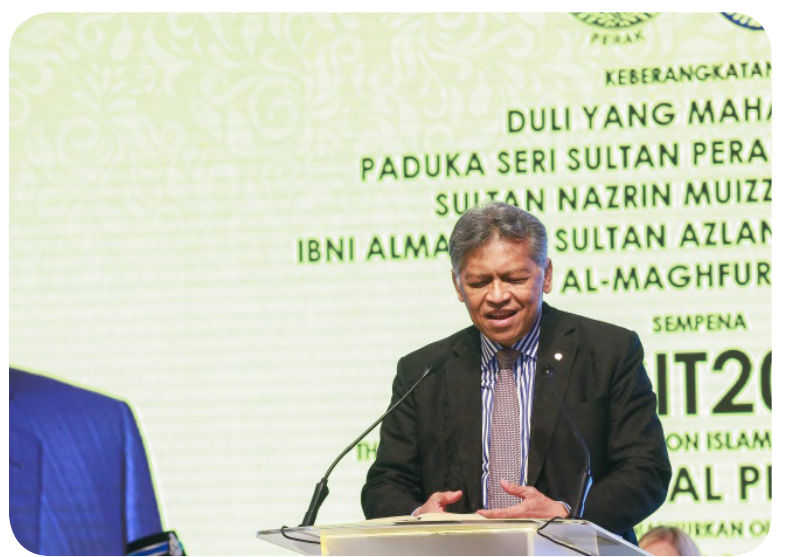

Although he had reached great heights, he remained true to his roots"fedupism"

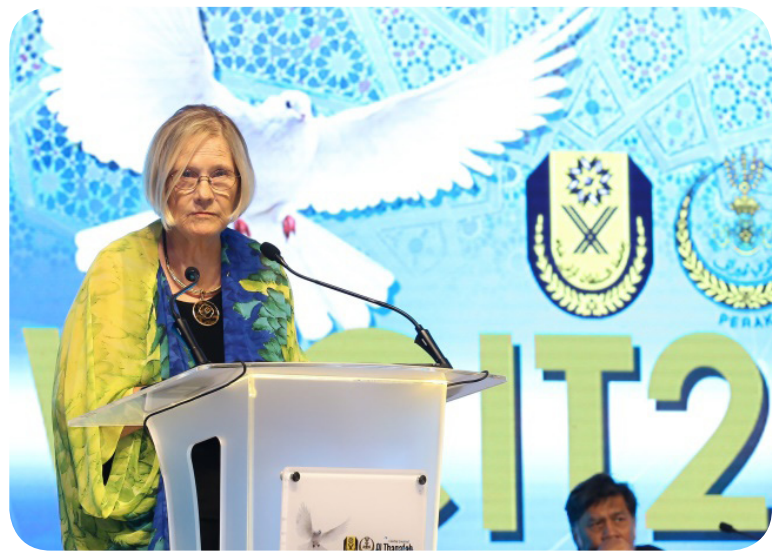

Formidable

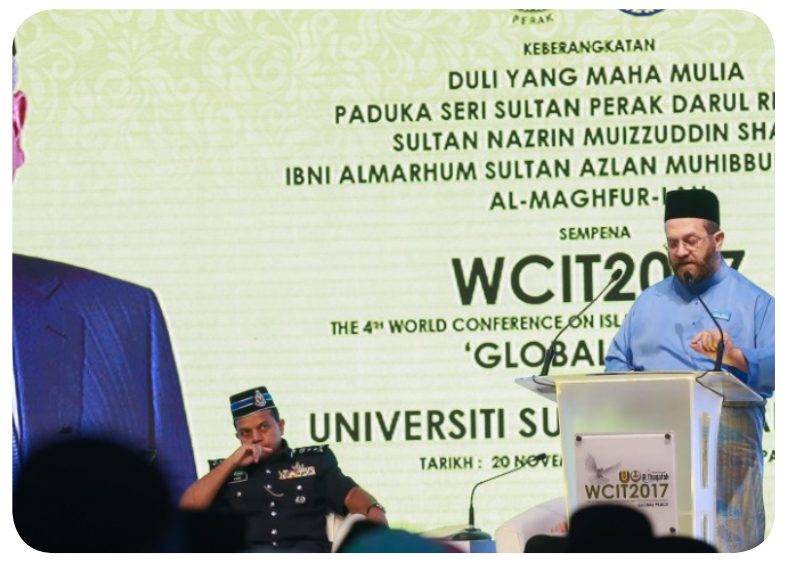

He came from across the seas...

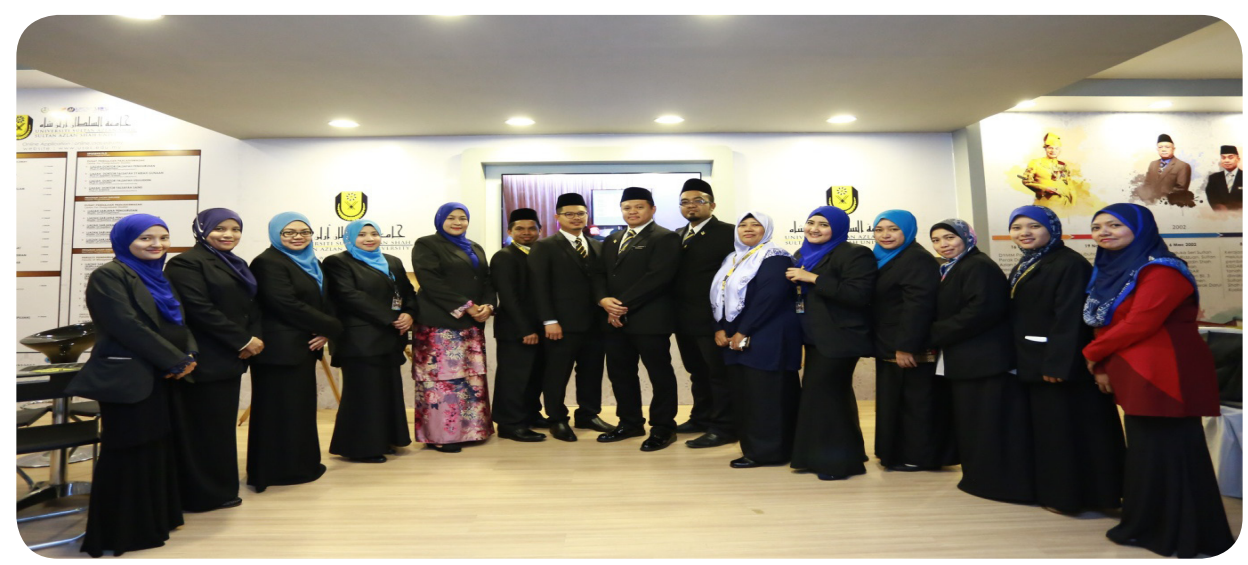

WCIT Secretariat

One for the camera, team! 


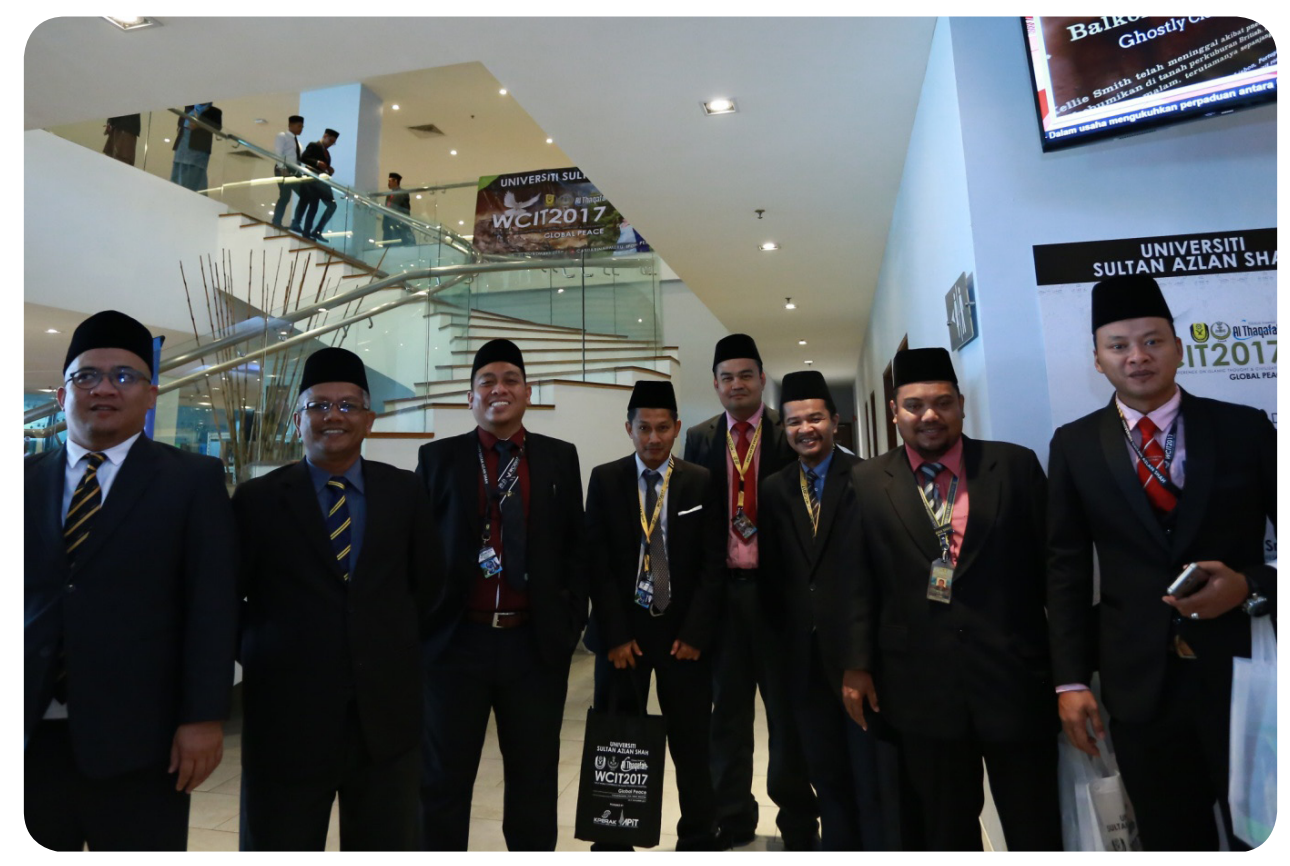

Cheese, guys! 


\title{
WCIT 2017 ORGANIZING COMMITTEE (As of 30/10/2017)
}

\author{
Royal Patron \\ DYMM Paduka Seri Sultan Perak
}

\section{Honorary Adviser}

Y.A.B. Dato' Seri DiRaja Dr. Zambry Abd. Kadir

\section{Conference Chair}

Tan Sri Prof. Dr. Nordin Kardi

Conferenc Director

Prof. Dato' Dr. Wan Sabri Wan Yusof

\section{Deputy Director}

Tn. Hj. Anas Md. Yusof

\section{Secretary General}

Zurul Naim Zainol Rashid

\section{Secretariat}

Hj. Mohd Hussin Dato' Seri Abdullah

Mohamad Amir Mohd Dahalan

Nurhanis Ishak

Anis Suria Mohd Zainudin

Haszril Mohd Sharuddin

Rus Shafrena Sapee @ Shafie

Fatin Hamimi Mat Resat

Nor Adila Azlan

Nur Sophia Rusli

Nor Razuana Amram

\section{Treasury and Finance}

Muhammad Nadhir Zamziba

Mohd Syahril Mohd Sani

\section{Editorial \\ English}

Ilyani Abd. Khalid

Nasuha Abdul Rahman Najib

Nur Hazwani Yussof

Noor Aishah Idrishah

Fasihah Raihani Abdul Rahman

Laily Murny Kamarulzaman

Norlaili Ahmad Razi

\section{Malay}

Muhammad Mustaqim Roslan

Mohd Nor Azren Kamarudin

Alfian Asmi

Muhammad Khalaf Razman 


\author{
Arabic (cont..) \\ Dr. Abdulghaffar Samae \\ Fauwaz Ebau \\ Dr. Affa Mohamed Saeed \\ Dr. Anwar AlMustafa
}

\title{
Preparation \& Conference Proceedings
}

Rosdiana Shaharum

Muhammad Nur Ikhsan Mohd Sefian

Hj. Tajul Azli Sahadan

Dr. Ir. Ahmad Faizul Shamsudin

\section{Sponsorship}

Mohd Faisal Bahari

\section{Technical, PA System \& IT}

Afzam Zulkifele

Amiruden Mohamed Sharif

Mohd Paizan Abd Rahman

Mohd Haidhir Mohamad Yusub

Noor Faridah Bani Omar

Norastkin Yahya

Publicity and Media Relations

Prof. Madya Abu Hasan Morad

Hj. Husaini Ibrahim

\section{Sales and Exhibitions}

Nor Fadzil Shoib

Halina Nasardin

\section{Special Tasks}

Prof. Madya Suhaimi Saidin

Dr. Roslan Abdul-Rahim

Prof. Madya Dr. Juzhar Jusoh

Prof. Madya Jamaluddin Helmi Hashim

Musa Mustafa

Protocol, Invitation, and Reception

Mohammad Burhan Mohd

Khalifa Mastura Hj. Abdul Aziz

Zainab Mohamad

Mohd Faizal Sufri

Nur Emyliana Zakaria

\section{Food, Souvenirs and Welcoming Dinner}

Prof. Madya Dr. Zatul Karamah Ahmad Baharul Ulum

Dr. Siti Nur Izyandiyana Ab. Hadi

Noormasitah Johan

Muhammad Nadzmi Zalizon

\section{Logistics, Transportation, Design \& Security}

Shahril Hezrin Shamsuddin

Muhammad Fitri Hilaluddin (Transportation)

Mior Ahmad Zaki Mior Aminuddin (Security)

Badiohisham Badiozaman (Design) 


\section{PROGRAM SCHEDULE \\ 4th WORLD CONFERENCE ON ISLAMIC THOUGHT AND CIVILIZATION \\ (WCIT2017) \\ THEME: ‘GLOBAL PEACE’}

19th NOVEMBER 2017

SUNDAY

\begin{tabular}{|l|l|}
\hline Time & Activity \\
\hline $8.45 \mathrm{pm}$ & WCIT2017 Concert \& Show \\
\cline { 2 - 3 } & End of Concert \& Show \\
\hline
\end{tabular}

DAY 1

20th NOVEMBER 2017 MONDAY

\begin{tabular}{|c|c|}
\hline Time & Activity \\
\hline $7.45 \mathrm{am}$ & Registration \\
\hline $9.15 \mathrm{am}$ & Arrival of VVIPs \\
\hline $9.45 \mathrm{am}$ & $\begin{array}{l}\text { Arrival of YAB Dato' Seri Diraja Dr. Zambry Abdul Kadir } \\
\text { Chief Minister of Perak Darul Ridzuan }\end{array}$ \\
\hline $10.00 \mathrm{am}$ & $\begin{array}{l}\text { Arrival of DYMM Paduka Seri Sultan Dr. Nazrin Muizzuddin Shah } \\
\text { lbni Almarhum Sultan Azlan Muhibbuddin Shah Al-Maghfur-Lah } \\
\text { His Royal Highness The Sultan of Perak Darul Ridzuan }\end{array}$ \\
\hline $10.10 \mathrm{am}$ & Quran Recitation \\
\hline $10.20 \mathrm{am}$ & $\begin{array}{l}\text { Welcoming Speech } \\
\text { Tan Sri Prof. Dr. Nordin Kardi } \\
\text { Vice Chancellor of Universiti Sultan Azlan Shah, Malaysia }\end{array}$ \\
\hline \multirow[t]{4}{*}{$10.30 \mathrm{am}$} & $\begin{array}{l}\text { Royal Keynote Address and Opening Ceremony } \\
\text { DYMM Paduka Seri Sultan Dr. Nazrin Muizzuddin Shah } \\
\text { lbni Almarhum Sultan Azlan Muhibbuddin Shah Al-Maghfur-Lah } \\
\text { His Royal Highness The Sultan of Perak Darul Ridzuan }\end{array}$ \\
\hline & Distinguished Session with His Royal Highness The Sultan of Perak Darul Ridzuan \\
\hline & Exit of His Royal Highness The Sultan of Perak Darul Ridzuan to Luncheon Hall \\
\hline & $\begin{array}{l}\text { Departure of His Royal Highness The Sultan of Perak Darul Ridzuan from the } \\
\text { Conference }\end{array}$ \\
\hline $1.00 \mathrm{pm}$ & Lunch and Zohor Prayer \\
\hline \multirow[t]{2}{*}{$2.30 \mathrm{pm}-4.00 \mathrm{pm}$} & Session I I Social Conflict \& Religious Extremism \\
\hline & Parallel Session (PSO1) \\
\hline $4.00 \mathrm{pm}-5.30 \mathrm{pm}$ & Session II | Philosophy \& Spiritual Tradition \\
\hline \multirow[t]{2}{*}{$5.30 \mathrm{pm}-7.00 \mathrm{pm}$} & Session III | Geo-Strategies \& Global Peace \\
\hline & End of Day One \\
\hline $8.30 \mathrm{pm}$ & $\begin{array}{l}\text { WCIT2017 Welcoming Dinner and Ambassador - Forum Session hosted at the } \\
\text { Official Residence of The Chief Minister of Perak Darul Ridzuan }\end{array}$ \\
\hline
\end{tabular}


DAY 2

21 st NOVEMBER 2017

TUESDAY

\begin{tabular}{|l|l|}
\hline Time & Activity \\
\hline $7.00 \mathrm{am}$ & Breakfast \\
\hline $8.30 \mathrm{am}-10.30 \mathrm{am}$ & Session IV I Power, Politics \& The Media \\
\hline $10.30 \mathrm{am}-12.00 \mathrm{pm}$ & Session V I Humanitarian Issues \& Universal Peace \\
\cline { 2 - 2 } & Session VI I Education \& Youth \\
\hline $12.00 \mathrm{pm}-1.00 \mathrm{pm}$ & Satellite Session I I Post-New World Order \\
\hline $1.00 \mathrm{pm}$ & Lunch and Zohor Prayer \\
\hline $2.30 \mathrm{pm}-3.30 \mathrm{pm}$ & Satellite Session II I Business as Catalyst for Global Peace \\
\hline $3.30 \mathrm{pm}-5.00 \mathrm{pm}$ & Satellite Session III I Women's Role in Peace Building \\
\hline $5.00 \mathrm{pm}-6.30 \mathrm{pm}$ & Satellite Session IV I Peace in Islam: Bridging Relations with World Communities \\
\hline $6.30 \mathrm{pm}$ & $\begin{array}{l}\text { WCIT2017 Closing Ceremony } \\
\text { Speech by } \\
\text { YAB Dato' Seri Diraja Dr. Zambry Abdul Kadir } \\
\text { Chief Minister of Perak Darul Ridzuan } \\
\text { Closing Ceremony by } \\
\text { YAB Dato' Seri Diraja Dr. Ahmad Zahid Hamidi } \\
\text { Deputy Prime Minister of Malaysia }\end{array}$ \\
\cline { 2 - 3 } & $\begin{array}{l}\text { End of Conference } \\
\text { WCIT2017 International Poem Festival }\end{array}$ \\
\hline $8.30 \mathrm{pm}$ & \\
\hline
\end{tabular}


